NBER WORKING PAPER SERIES

\title{
FEDERAL OVERSIGHT, LOCAL CONTROL, AND THE SPECTER OF "RESEGREGATION" IN SOUTHERN SCHOOLS
}

\author{
Charles T. Clotfelter \\ Helen F. Ladd \\ Jacob L. Vigdor \\ Working Paper 11086 \\ http://www.nber.org/papers/w11086
}

\author{
NATIONAL BUREAU OF ECONOMIC RESEARCH \\ 1050 Massachusetts Avenue \\ Cambridge, MA 02138 \\ January 2005
}

The views expressed herein are those of the author(s) and do not necessarily reflect the views of the National Bureau of Economic Research.

(C) 2005 by Charles T. Clotfelter, Helen F. Ladd, and Jacob L. Vigdor. All rights reserved. Short sections of text, not to exceed two paragraphs, may be quoted without explicit permission provided that full credit, including () notice, is given to the source. 
Federal Oversight, Local Control, and the Specter of "Resegregation" in Southern Schools Charles T. Clotfelter, Helen F. Ladd, and Jacob L. Vigdor

NBER Working Paper No. 11086

January 2005

JEL No. I28

\begin{abstract}
$\underline{\text { ABSTRACT }}$
Analyzing data for the 100 largest school districts in the South and Border states, we ask whether there is evidence of "resegregation" of school districts and whether levels of segregation can be linked to judicial decisions. We distinguish segregation measures indicating the extent of racial isolation from those indicating the degree of racial imbalance across schools. For the period 1994 to 2004 the trend in only one measure of racial isolation is consistent with the hypothesis that districts in these regions are resegregating. Yet the increase in this measure appears to be driven by the general increase in the nonwhite percentage in the student population rather than policydetermined increases in racial imbalance. Racial imbalance itself shows no trend over this period. Racial imbalance is nevertheless associated with judicial declarations of unitary status, suggesting that segregation in schools might have declined had it not been for the actions of federal courts. This estimated relationship is subject to a lag, which is in keeping with the tendency for courts to grant unitary status only if districts agree to limit their own freedom to reassign students.

Charles T. Clotfelter

Department of Economics

Duke University

Box 90245

Durham, NC 27708

and NBER

charles.clotfelter@duke.edu

Helen F. Ladd

Department of Economics

Duke University

Box 90245

Durham, NC 27708

hladd@pps.duke.edu

Jacob L. Vigdor

Department of Economics

Duke University

Box 90245

Durham, NC 27708

jacob.vigdor@duke.edu
\end{abstract}


Federal Oversight, Local Control, and the Specter of "Resegregation" in Southern Schools ${ }^{1}$

\author{
Charles T. Clotfelter, Helen F. Ladd, and Jacob L. Vigdor
}

\title{
I. Introduction
}

The historic movement toward racially integrated schools, initiated by Brown v. Board of Education and advanced by subsequent Supreme Court decisions, was marked by a dramatic decline in the number of students attending "racially identifiable" schools. In the South, the percentage of black students enrolled in schools with 90-100\% nonwhite enrollments fell from 100\% in 1954 to $78 \%$ in 1968 and to $25 \%$ by 1972 . Consistent with this decline, the comparable percentage for the country as a whole fell from $64 \%$ in 1968 to less than $34 \%$ in both 1980 and 1989 (Clotfelter 2004, p.56).

Since 1990, however, this measure of racial isolation has begun to creep up again. It rose to $37.4 \%$ for the nation by the fall of 2000 and between 1991 and 2000 it increased in every region of the country (Clotfelter 2004, p. 56). These developments have raised alarms about the "resegregation" of schools. Observers have expressed special concern about the South, where Jim Crow apartheid gave way to sweeping change in the late 1960s, transforming schools in that region from the most segregated to the least segregated in the country.

A prominently cited culprit behind this apparent turnaround is the federal judiciary.

${ }^{1}$ We are grateful to John Charles Boger and Jeffrey Kling for comments on an earlier version of this paper and to Roger Aliaga Diaz, Janeil Belle, Demarron Berkley, Megan Fotheringham, Felicity Kolp, Robert Malme, and Dallas Stallings for research assistance. 
According to Orfield and Eaton (1996, p. 1), the key to understanding the reversal in trends after 1990 is a pair of Supreme Court decisions in 1991 and 1992. The 1991 decision, Board of Education of Oklahoma v. Dowell, allowed districts to be released from judicial control once they had been declared "unitary" and thus to be free to assign students to schools, if they wished, by neighborhood of residence. Owing to the pervasive racial segregation in existing housing patterns, the use of such neighborhood-based attendance zones quite naturally tends to produce de facto segregation in schools. In the second decision, Freeman v. Pitts (1990), the Court effectively eased the requirements necessary for a district to be declared unitary. ${ }^{2}$ Orfield and Eaton (1996, p. 1) state:

these historic High Court decisions were a triumph for the decades-long powerful, politicized attacks on school desegregation. The new policies reflected the victory of the conservative movement that altered the federal courts and turned the nation from the dream of Brown toward accepting a return to segregation.

The NAACP Legal Defense Fund's 2000 annual report concurs: "When there are findings of unitary status, as in Oklahoma City and Norfolk, resegregation has become the rule" (NAACP 2000, p. 8).

Whatever its causes, not everyone agrees that resegregation is in fact occurring. Logan (2004) argues that increases in measures of racial isolation are merely a reflection of the country's changing racial composition and that schools are no more segregated today than they were before these court decisions were handed down. Using data on public schools from across

${ }^{2}$ Rather than having to eliminate simultaneously all vestiges of past discrimination, as enumerated by Green v. New Kent County (1968) in order to achieve unitary status, the Court ruled that these factors only needed to be addressed successfully sometime. 
the country, he documents the general increase in the proportion of nonwhite students between 1990 and 2000. He shows that the proportion of all students attending predominantly white schools declined, for example, while the percentage attending schools $90 \%$ or more nonwhite increased (Logan 2004, p. 9). According to Logan, it is the increase in the nonwhite share and the consequent increase in predominantly nonwhite schools that raises measures of racial isolation such as the percentage of black students attending 90-100\% nonwhite schools.

Our aims in this paper are two-fold. One goal is to examine the extent to which "resegregation" has occurred during the past 10 years, with particular reference to the 100 largest districts in Southern and near-Southern (or "Border") states. We focus on districts in these states because, given their policy of official segregation before 1954, they have been a focal point for the widely-expressed concern about resegregation. ${ }^{3}$ The second goal is to determine what role the courts have played in whatever resegregation has occurred, with particular attention to judicial declarations of unitary status and the rulings in the Fourth Circuit.

To preview our conclusions, we find first that whether and to what extent segregation appears to be reemerging differs according to the construct used to measure segregation. If we define segregation as racial isolation, we find some evidence of increasing segregation across schools within districts during the 1993-2003 period, but only when we use the specific measure cited at the beginning of the paper, the percentage of black students attending schools 90-100\%

${ }^{3}$ Following Orfield and Monfort (1992, p. 2), these regions are defined as follows: Border: Delaware, District of Columbia, Kentucky, Maryland, Missouri, Oklahoma, West Virginia; South: Alabama, Arkansas, Florida, Georgia, Louisiana, Mississippi, North Carolina, South Carolina, Tennessee, Texas, Virginia. In fact, public schools had been segregated by law not only in the eleven states of the former Confederacy, the six Border states, and the District of Columbia, but also in parts of Kansas, Arizona, and New Mexico (Clotfelter 2004, p. 18) 
nonwhite. If we define segregation not as racial isolation, but rather as racial imbalance within districts, we find, somewhat to our surprise, no evidence of resegregation. Nor, however, do we find any evidence that segregation is declining. Thus, within districts, the trends in school segregation contrast markedly with the trends for the same period in residential segregation (measured at the metropolitan level), which decreased quite substantially in some Southern metropolitan areas (Glaeser and Vigdor, 2003). The decline in residential segregation creates the possibility that, even in the absence of rising school segregation, were it not for judicial rulings of unitary status, racial segregation across schools might have declined.

Second, we find some suggestive links between the decisions of federal courts and school segregation as reflected in two measures of racial imbalance, but these findings are by no means definitive proof that court decisions have opened the door to resegregation. We find higher levels of racial imbalance among districts that were declared unitary before 1993 than among those which have never been so declared. We also find an increase over time in racial imbalance among districts in the Fourth Circuit, which finding could be the result of decisions unique to that circuit. With the exception of one specification, we find no association between judicial rulings or jurisdictions and a measure of racial isolation, probably because that measure is so strongly influenced by demographic changes. Since those demographic changes are outside the control of district policymakers, it is difficult to isolate the effects of judicial action on the school assignment decisions over which they do have control.

Section II of the paper discusses various measures of segregation and section III documents changes over the 10-year period for our sample of 100 large districts. Section IV provides an overview of legal issues related to school desegregation cases, with emphasis on the 
role of declarations of unitary status and decisions in the Fourth Circuit. That historical overview serves as background to the empirical investigation of their effects on segregation in section $\mathrm{V}$. The paper ends with a brief concluding section.

\section{Recognizing "Resegregation"}

The "segregation" referred to in the Brown decision was a system of laws whereby students of different races were assigned to separate schools with separate faculties. ${ }^{4}$ In contemporary discussions in the school context, the term segregation has become an attribute of enrollment patterns by race - typically across schools within a district - and is typically measured in quantitative terms so that one pattern can be judged more segregated than another.

Contemporary measures of segregation can be grouped into two main categories: measures of racial isolation and measures of racial imbalance.

\section{Racial Isolation}

The measure used at the beginning of this paper, the percentage of black students in schools that are $90-100 \%$ nonwhite, is one widely used measure of racial isolation. By summarizing the extent to which black students are in schools primarily with other minority students, it indicates the degree to which black students are isolated from (non-Hispanic) white students. Its focus on the nature of schools attended by black students reflects the historical fact

${ }^{4}$ The preponderant importance of de jure segregation at the time of Brown is also illustrated by the emphasis placed on state support of segregation in a statement by prominent social scientists that was submitted as part of an amicus brief to the Court in 1953 ("The Effects of Segregation..." 1953). 
that blacks were both the principal minority group in the South and the group whose history of subjugation and discrimination made its legal status central to the Brown case.

In recent years, owing to the growth in Hispanic and other nonwhite enrollments, the percentage of nonwhite students who are black has fallen in many districts. Thus it is useful to distinguish this first measure from a closely related measure of racial isolation that also focuses on the schools attended by black students: the percentage of black students in schools that are 90100 percent black. In contrast to the prior measure, this one measures the extent to which black students are concentrated in schools with students like themselves. In the absence of Hispanic or other non-black minority students, the two measures would of course be identical. In districts with a growing number of Hispanic students, however, trends in the two measures could well diverge.

A somewhat different measure of racial isolation, defined once again from the perspective of black students, is the rate at which they attend school with other black students. Also referred to as the exposure rate of black students to black students, this rate is:

$$
\mathrm{E}_{\mathrm{bb}}=\left[\sum \mathrm{B}_{\mathrm{j}} \mathrm{b}_{\mathrm{j}}\right] / \sum \mathrm{B}_{\mathrm{j}}
$$

where $B_{j}$ is the number of black students in school $j$ and $b_{j}$ is the school's percentage of black students. Equivalent to the proportion black in the typical black student's school, this exposure rate is one way of indicating how isolated black students are from students of other races.

Importantly, measures of racial isolation are not independent of a district's overall racial composition. In general the higher is the proportion of black or of nonwhite students, depending on the measure used, the higher will be one of these measures of isolation. Stated differently, measures of racial isolation incorporate into a single measure any imbalance in the racial mix of 
students across schools as well as the overall racial composition of the district. As a descriptive device, measuring segregation by means of an index of racial isolation is undoubtedly useful. From the perspective of district policy makers, however, who are likely to have far greater control over the extent to which students of different races are distributed among schools in a balanced or unbalanced manner than over the racial mix of students in the district, it is useful to have a segregation measure that isolates the aspect of enrollment patterns over which they have more control. Segregation indexes that measure racial imbalance fit this requirement in that they are not a function of a school district's racial composition.

\section{Racial Imbalance}

Such indexes are designed to measure the extent to which students of a particular race are unevenly distributed across schools within the district. At one extreme, segregation would be complete if members of each racial group attended schools with members of their own race alone. At the other, there would be no segregation, according to this approach, if all schools had the same racial composition, which by definition would be the racial composition of the district as a whole. The calculation of any measure of racial imbalance must begin with a decision about which racial groups to highlight. For most of our analysis of racial imbalance, we look at the balance between white and nonwhite students.

One useful measure of racial imbalance is a gap-based segregation index, $S$, which takes the following form for segregation within district $k$ :

$$
S_{k}=\left(n_{k}-E_{w n}\right) / n_{k},
$$

where $n_{k}$ is the proportion of the district's students who are nonwhite and in this case $E_{w n}$ is the 
exposure rate of whites to nonwhites, defined as

$$
E_{w n}=\left[\sum W_{j} n_{j}\right] / \sum W_{j},
$$

$W_{j}$ is the number of whites in school $j$, and $n_{j}$ is its nonwhite percentage. The exposure rate $E_{w n}$ can be interpreted as the nonwhite percentage in the typical white student's class, and can range from zero, where schools are fully separated by race, to $n_{j}$, where they are racially balanced. Thus the segregation index is the difference between the maximum exposure rate of whites to nonwhites, which is simply the nonwhite share of students in the district, and the actual exposure rate, expressed as a fraction of the maximum. The segregation index runs from 0 , which represents no segregation, to 1 , which represents complete segregation.

Another well-known measure of racial imbalance is the dissimilarity index..$^{5}$ This index, which also runs from 0 to1, has a simple intuitive interpretation: it indicates the proportion of any one racial group of students that would have to switch schools to achieve racial balance across the district. The closer is the number to 1 , the more segregated is the district. Though the dissimilarity index is commonly used in studies of residential segregation, we prefer the gapbased measure of segregation which we have used extensively in our previous research of school segregation in North Carolina. Though not of particular usefulness for this paper, a major advantage of the gap-based measure is that it can be readily decomposed into segregation between and within schools.

A drawback to measures of racial imbalance such as the gap-based segregation index and

${ }^{5}$ The index of dissimilarity is defined as $D=0.5 \sum\left|N_{j} / N-W_{j} / W\right|$, where $N$ and $W$ are total nonwhite and white enrollment in a district, and $N_{j}$ and $W_{j}$ are the nonwhite and white enrollment in school $j$. 
the dissimilarity index is that, because they are calculated by dividing the relevant population into two groups, they cannot reflect differences in racial balance among multiple groups. One index that is able to account for multiple groups is the entropy index, based on Theil's information theory where $g$ indexes racial groups and $j$ indicates schools. A district's entropy index is

$$
\mathrm{H}=\sum_{j} \mathrm{t}_{\mathrm{j}}\left(\mathrm{F}-\mathrm{F}_{\mathrm{j}}\right) / \mathrm{F}
$$

where $t_{j}$ is school $j$ 's proportion of district enrollment,

$$
\begin{aligned}
& \mathrm{F}_{\mathrm{j}}=\sum_{g} \mathrm{p}_{\mathrm{gj}} \ln \left(1 / \mathrm{p}_{\mathrm{gj}}\right), \text { and } \\
& \mathrm{F}=\sum_{g} \mathrm{p}_{\mathrm{g}} \ln \left(1 / \mathrm{p}_{\mathrm{g}}\right),
\end{aligned}
$$

where $\mathrm{p}_{g \mathrm{j}}$ is group $g$ 's proportion in school $j$, and $\mathrm{p}_{g}$ is group $g$ 's proportion of district enrollment. ${ }^{6}$ We divide students into four groups: white, black, Hispanic, and other nonwhites. Like the other two measures of racial imbalance, noted above, $\mathrm{H}$ has a maximum value of 1 , indicating schools that are completely separated by race, and a minimum value of 0 , indicating racially balanced schools.

Level of Analysis

Quite apart from the concept of segregation employed, another issue central to the measure of school segregation is the level of analysis. The standard approach is to measure segregation across schools within a single school district. That is the approach implicit in the summary measures cited at the beginning of the paper and also in our discussion of the various

${ }^{6}$ For expositions of this index, see, for example, Theil 1972 or Iceland 2002. 
definitions of racial segregation. Although we have used data at the classroom level to measure segregation in some of our previous work (Clotfelter, Ladd, and Vigdor 2003), we are restricted to data collected at the school level for the analysis in this paper. ${ }^{7}$ In some of our work, we have also examined segregation at the metropolitan area level, making it possible to separate segregation attributable to racial disparities within school districts - the basis for conventional measures - from that due to racial disparities between school districts. It turns out that changes in school segregation at the metropolitan level between 1970 and 2000 were affected by contrary movements in these two components: the movement of whites to suburban school districts caused segregation of the second variety to increase at the same time that within-district segregation was declining. ${ }^{8}$

In this paper, we restrict our attention to segregation within school districts. Consequently changes in measures of segregation based on imbalance, which effectively abstract from any changes in the racial composition of the district, will fail to pick up any new segregation that results from growing racial disparities between districts within a metropolitan area. In contrast, changes in measures of racial isolation at the district level inevitably reflect in part changes in the

${ }^{7}$ In our earlier work, we used classroom-level data on racial composition for the entire state of North Carolina. We found only a minimal amount of within-school segregation in elementary schools. At secondary schools, which are more likely to employ tracking and other curricular policies that separate students on different academic tracks, within-school segregation is more prominent. We found evidence that all forms of segregation, both within- and betweenschool, increased between 1994 and 2001. These increases were found in both urban and rural districts, and in parts of the state varying widely in terms of racial composition.

${ }^{8}$ For an explanation of the decomposition into these two parts, see Clotfelter (1999) or Clotfelter, Ladd, and Vigdor (2003); for a discussion of these changes over time, see Clotfelter (2004, chapter 2). The last of these also includes the effect of private school enrollment, but the quantitative effect of that aspect is not large. 
racial mix of students in each district, changes that may be the result of differential movement of students by race across districts within a metropolitan area. In particular, the movement of white students out of city districts either to suburban districts or to private schools will result in rising nonwhite proportions in city districts, and, most likely, into greater racial isolation. Because they reflect different aspects of racial segregation, we therefore draw attention both to measures of racial isolation and to measures of imbalance to assess whether recent enrollment trends justify the characterization of "resegregation." We turn now to that assessment.

\section{Segregation Trends in the 100 Largest Southern Districts}

We base our analysis on enrollment data for the largest 100 districts in the South and Border regions (based on 2001/02 enrollments), some of which we have collected ourselves directly from the districts. These districts represent some $15 \%$ of total K-12 enrollment in the South and Border regions in the 2001/02 school year. ${ }^{9}$ In size, these districts ranged from 31,190 in Calcasieu Parish (Lake Charles) to 365,343 in Dade County (Miami), Florida. In racial composition, they ranged from $13.3 \%$ nonwhite in Pasco County (suburban Tampa) to $97.5 \%$ in Birmingham, Alabama.

Table 1 presents summary statistics for a number of district characteristics as well as the six segregation measures defined in the previous section. Means and standard deviations are

9 Percentage based on K-12 enrollments from the NCES Common Core of Data. For districts that were subject to consolidation or annexation, we included all of the subsequent components throughout the time period of analysis. For school years through 2002/03, the data were generally available in the Common Core of Data. To supplement these publicly available data with information from the most recent school year, we requested from individual districts comparable data on enrollment by race of each school for the 2003/04 year. A complete listing of these districts is given in Appendix Table 1. 
reported for the 1993/94 and 2003/04 school years, which comprise the endpoints for our panel dataset. All summary statistics are weighted by enrollment. Most school districts in our sample experienced substantial population growth during this time period, reflecting strong growth rates in the region as a whole. Almost all of this growth occurred in the nonwhite population: average white enrollment shows virtually no trend, and the nonwhite share of enrollment increased by ten percentage points over ten years. The bottom panel of the table refers to information related to judicial decisions to which we will return in section IV. At this point, we simply note that districts in the Fourth Circuit serve about 1 out of 4 students in the sample and that districts in the Eleventh District serve more than a third of the students.

With respect to trends in segregation, the table shows a small increase in one measure, the dissimilarity index, and a substantial increase in the percent of black students in 90-100 percent nonwhite schools. As shown in the first row, that measure of racial isolation increased from about 27 percent in 1993-94 to 34 percent in 2003/04. Intriguingly, this trend does not appear to be attributable to an increased tendency for blacks to attend overwhelmingly black schools. The share of black students attending 90-100\% black schools fell slightly and the exposure rate of blacks to other blacks ended the decade unchanged. Thus, any increase in racial isolation of black students appears to have far more to do with the growth in proportions of students who are neither non-Hispanic white nor non-Hispanic black, the majority of whom are likely to be Hispanic, than with changes in enrollment patterns of black and white students.

Consistent with the view that district-wide demographic changes are driving the growth in the proportion of black students in 90-100 percent nonwhite schools, the measures of racial imbalance show little or no increase in segregation over time. Thus, aside from changes over 
time in the racial composition of enrollments in the 100 large districts, we find no strong evidence of a rise in racial segregation.

Figure 1 plots the five segregation measures over time, incorporating enrollment data from intervening years. ${ }^{10}$ The graph confirms the basic summary statistics in Table 1 . Only the proportion of black students attending 90-100\% nonwhite schools shows any significant time trend over this ten-year period, a very smooth upward progression spanning the entire ten-year period. The other five indices, including the proportion of blacks attending $90-100 \%$ black schools, display only a small amount of fluctuation over this time period, with no discernible drift either upward or downward.

The contribution of students who are neither white nor black to trends in racial isolation is underscored by Figure 2, which displays the racial composition of the school attended by the typical white, black, Hispanic, or other nonwhite student in 1993/94 and 2003/04. The graph shows that students of all races, including whites, tended to witness decreases in the proportion of non-Hispanic white students in their schools between 1993/94 and 2003/04. The average share of black students, though generally higher for blacks than for students of other races, remained virtually unchanged for students of every race. Whites, Hispanics, and students of other races attended schools that were about $25 \%$ black in both 1993/94 and 2003/04. The typical black student attended a school slightly more than $45 \%$ black in both years, as indicated by the black-black exposure rate in Table 1. In the case of each racial group, the reduction in white student share was almost exactly compensated by an increase in the proportion of Hispanic

\footnotetext{
${ }^{10}$ For the purpose of making the figure, values were interpolated for five districts with missing data in several years.
} 
and other nonwhite students.

The relative stability of mean values shown in Figure 1 may mask considerable variation across particular types of districts or between regions. Table 2 shows mean values for two segregation indices, one measure of racial isolation and one of racial imbalance, at two points in time for various categories of districts. We categorize districts by region, and, whether central city, suburban or consolidated, and by percent nonwhite enrollment in the initial year of the panel, 1993/94 as well as by federal court circuit.

The regional breakdown is of general interest because of the regions' different histories. Whereas districts in the Border region generally began to comply with Brown almost immediately, those in the South were famously reluctant, often aggressively so. The table shows that the Border districts in the sample tended to have higher levels of racial imbalance and racial isolation, as well as greater rates of white enrollment loss. However, the ten-year trends in racial separation, whether measured by imbalance or by racial isolation, appear quite similar in both regions.

As shown by the next set of categories, school segregation is most severe in districts that serve central cities of metropolitan statistical areas (MSAs). More than three of every four students enrolled in these districts in the 1993/94 school year were nonwhite. Over the decade analyzed here, segregation as measured by imbalance declined somewhat in these districts while the isolation of black students rose, possibly reflecting the substantial losses in white enrollment over the period. While continued "white flight" is a sensible explanation for the increased isolation of black students in central city districts, trends in suburban and city-county 
consolidated districts imply a more complicated story. ${ }^{11}$ In these districts, where losses in white enrollment were much less severe, the proportion of black students in 90-100\% nonwhite schools increased just as rapidly, if not more, than in central city districts. Among the 42 suburban districts in the sample, for example, ten experienced increases in their percentage nonwhite of 20 points or more. By 2003/04, seven suburban districts had nonwhite percentages of $80 \%$ or more. White enrollments declined the least rapidly in consolidated districts, which helped served to stabilize their racial compositions. Over the 10-year period, none of the 36 consolidated districts experienced an increase in the nonwhite percentage as large as 20 points.

Classifying districts by initial percent nonwhite as in the next panel of the tables reveals some noteworthy differences in trends. Rates of white enrollment loss were largest in majoritynonwhite districts, a pattern confirmed by the scatterplot in Figure 3. As white enrollment declined in these districts, the share of black students attending overwhelmingly nonwhite schools increased, as shown in Table 3 . That the segregation indices posted either very modest gains or declines in the face of these losses implies that districts managed to maintain a similar degree of racial balance in attendance patterns across schools despite the change in racial composition. A somewhat different pattern emerges in overwhelmingly white school districts.

${ }^{11}$ For purposes of this analysis, school districts serving independent cities or cities that attained county-equivalent status prior to World War II are classified as central city districts. Districts affected by this classification rule include Orleans parish (coterminous with the City of New Orleans since 1870), Baltimore City, St. Louis City, Newport News, Norfolk, Virginia Beach, and Washington, DC. Our choice of cutoff date reflects the onset of rapid suburbanization in the postwar era. Cities consolidating with their overlying counties after World War II, including Jacksonville, Miami, Nashville, Augusta, Lexington, and Louisville, are classified as consolidated districts. 
The final panel refers to differences by federal judicial circuit. ${ }^{12}$ We return to these differences later in the paper.

For a comprehensive overview of changes in segregation and racial isolation between 1993/94 and 2003/04, Figures 4 and 5 show scatterplots of index values from the two years, with a 45-degree line separating those districts experiencing increases from those exhibiting decreases. In Figure 4, the gap-based measure of racial imbalance displays some mean-reversion over time. Districts experiencing increases in segregation tended to have low levels to start with, while those with high levels were more likely to decrease than increase. Figure 5, which plots the share of black students attending $90-100 \%$ nonwhite schools in the two years, shows a cluster of points near zero in both years, but a generally larger collection of points above the 45-degree line, highlighting the general increase in this measure of racial isolation.

\section{Changes in the Legal Landscape}

We now turn to the more complex question of what role judicial actions have played in the segregation patterns just described. The data presented so far suggest that the relaxation of judicial constraints may be far less implicated in the changes than analysts such as Orfield have claimed. Recall that trends in measures of racial isolation such as the percentage of black students in 90-100 percent nonwhite schools have been used to support the notion that racial segregation in schools is increasing. Yet, as we have already shown, the rise in this measure is

12 The federal judicial circuits for the relevant states containing the sample districts are: Fourth: Maryland, North Carolina, South Carolina, and Virginia; Fifth: Louisiana, Mississippi, and Texas; Sixth: Kentucky and Tennessee; Eighth: Missouri; Eleventh: Alabama, Florida, and Georgia; D.C.: D.C. 
largely attributable to the changing demographics of the districts in our sample. Because our measures of racial imbalance are not affected by such changes, they provide a "cleaner" measure of the segregation that results from district level decisions about student assignment. Given that these measures show no upward trend over time, one might conclude that there is nothing left to be explained by the court decisions. At the same time, however, because residential segregation declined during the same 10-year period, it could be that in the absence of judicial decisions, segregation in the schools would have declined. In addition, because court decisions apply to particular districts or sets of districts, such decisions could help explain the variation in trends across districts.

Before turning to our empirical analysis we provide some background regarding federal judicial rulings in desegregation cases, with emphasis on those rulings relating to racial balance in school assignments and declarations of unitary status. As we will show, identifying the judicial actions relevant to our empirical analysis is not an easy task. We begin with rulings in which the courts declared districts to be unitary, and, hence, no longer subject to active judicial oversight.

\section{Unitary Status}

The Supreme Court's 1968 decision in Green v. County School Board of New Kent County stated emphatically that segregated, or "dual," school systems could not meet the admonition promulgated in Brown unless racially identifiable schools were eliminated. ${ }^{13}$ As one of six factors set down in this case, this pupil assignment criterion suggested, but did not dictate, racial balance as a desideratum. Three years later, in Swann v. Charlotte-Mecklenburg Board of

\footnotetext{
13391 U.S. 430 (1968). See also Boger (2000, p. 1733).
} 
Education, the Court came close to ordering just that, stating "a presumption against schools that are substantially disproportionate in their racial composition." ${ }^{14}$ Ratifying a plan that paired schools and transported students across the district to achieve racially balanced schools, the decision set off a series of lower court decisions in the South and Border states that employed methods such as these to achieve racially balanced schools. ${ }^{15}$ In the same decision, however, the Court also implied that court supervision, and thus extraordinary measures to maintain racial balance in schools, along with racial guidelines for schools, would not be a permanent state of affairs. Once deemed unitary, a school district would not have to make continual adjustments to maintain racially balanced enrollments in its schools. ${ }^{16}$

In Green and Swann, therefore, the Court set the stage for a district to be freed from active judicial oversight once it had been declared unitary. In two decisions, Board of Education of Oklahoma v. Dowell (1991) and Freeman v. Pitts (1992), the Supreme Court clarified what it meant to be deemed unitary. ${ }^{17}$ After a district has shown a good-faith effort to eliminate vestiges of past segregation and has satisfied the requirements of Green, it stated, the district can be declared unitary, after which any racial imbalance among its schools arising from residential

14 "No per se rule can adequately embrace all the difficulties of reconciling the competing interests involved; but in a system with a history of segregation the need for remedial criteria of sufficient specificity to assure a school authority's compliance with its constitutional duty warrants a presumption against schools that are substantially disproportionate in their racial composition." Swann v. Charlotte-Mecklenburg Board of Education, 402 U.S. 1, 26 (1971).

15402 U.S. 1 (1971); Armor (1995).

16402 U.S. 1, 31 (1971). Some critics maintain that lower courts ignored this distinction, instead equating desegregation with racial balance. See, for example, Armor (1995, p. 32).

${ }^{17} 498$ U.S. 237 (1991); 503 U.S. 467 (1992); Boger (2000, p. 1737). 
segregation would be permitted. ${ }^{18}$ Since desegregation orders often entailed extensive micromanagement, very often extending down to the detail of specifying precise attendance boundaries for individual schools, receiving a unitary status declaration would appear to free a district to determine student assignments for itself. In fact, however, the practical import of unitary status has rarely been as simple as the evaporation of outside control, as we discuss below.

Fourth Circuit Rulings on Race-conscious Assignment

A related but distinct legal question is whether a district not under court order to desegregate - either by having been declared unitary or by never having been subject to an order - can base school assignments by race. Needless to say, any desegregation plan that aimed at racial balance had to devise assignment patterns that would keep all schools in a district close to the district's overall racial composition. But in a series of decisions meant to apply to districts not under court order, the Fourth Circuit Court of Appeals ruled that race could not be used in assigning students, presumably making it impossible for a district to maintain racial balance through the adjustment of student assignments. ${ }^{19}$ Boger (2000, p. 1794) warns that these decisions could have dire consequences:

${ }^{18}$ See, for example, Armor (1995, pp. 52-54); Orfield and Eaton (1996, p. 2) state: "These decisions view racial integration not as a goal that segregated districts should strive to attain, but as a merely temporary punishment for historic violations, an imposition to be lifted after a few years. After the sentence of desegregation has been served, the normal, "natural" pattern of segregated schools can be restored."

${ }^{19}$ The decisions are Capacchione v. Charlotte-Mecklenburg Schools, 57 F. Supp. 2d 228 (W.D.N.C. 1999), Eisenberg v. Montgomery County Public Schools, 197 F.3d 123 (4 ${ }^{\text {th }}$ Cir. 1999), and Tuttle v. Arlington County School Board, 195 F.3d 698 (4 ${ }^{\text {th }}$ Cir. 1999). For a discussion of these cases, see Boger (2000, pp. 1721, 1740, and 1780). 
if willing school boards cannot assign students by race or ethnicity, we risk a rapid return to a time when each school child could, and did, identify "white schools" and "black schools" simply by reference to the predominant race of the children attending them. Far more certainly than school boards' good-faith efforts to assure of educational diversity, this de facto resegregation of our schools will re-create the conditions condemned in Brown in 1954.

As of this writing, the legal status of these Fourth Circuit rulings remains unsettled. The Supreme Court's 2003 decision in Grutter v. Bollinger reaffirmed that race could be taken into consideration in making admissions decisions to a law school if this aspect were merely one part of a full evaluation of candidates; it is as yet uncertain how this ruling will be applied to K-12 school assignment plans that take race into account. ${ }^{20}$ And whether these Fourth Circuit rulings could have influenced the decisions of school districts before 1999, when they were handed down, is highly uncertain. Only to the extent that school districts in the Fourth Circuit anticipated the subsequent rulings could the rulings have had an impact before 1999.

Variations in the Meaning of Unitary Status

Overlaying these general legal issues is local particularity. Each district has its own particular history of policies, political forces, issues in dispute, rulings, and compliance, and the meaning of unitary status has likewise differed across districts, to be sure. A few districts seem to present clear cases of how changes in judicial doctrine can open the door to de facto

${ }^{20}$ As of this writing, two federal district courts have allowed racially conscious school assignment plans, citing Grutter and Gratz, but one circuit's court of appeals has disallowed another such plan, citing the same decisions. See Comfort v. Lynn School Committee (2003), McFarland v. Jefferson Co. Public Schools (2004), and Parents Involved in Community Schools v. Seattle School District, No. 1 (2004). 
segregation. Two such examples are Charlotte-Mecklenburg and Winston-Salem/Forsyth, North Carolina. After tiring of the extensive pairing and busing plan made famous in the Swann case for more than 20 years, Charlotte-Mecklenburg in 1992 launched a magnet school program, hoping to attract whites to downtown schools voluntarily, with racial balance maintained by quotas for acceptance. It was these quotas that were challenged, successfully, establishing one of the Fourth Circuit's rulings against race-conscious assignments (Capacchione v. CharlotteMecklenburg Schools, 2001). The school board adopted a new student assignment plan (in the fall of 2002) allowing families limited choice among schools, but which guaranteed most students the option of attending neighborhood schools. ${ }^{21}$ The apparent result of this change in assignment plans was an increase in racial isolation. Whereas the percentage of black students attending $90-100 \%$ minority schools in 1995 was $4 \%$; this share rose to $11 \%$ in $2001 / 02$ and $23 \%$ in 2003/04. In the case of Charlotte-Mecklenburg, the change in assignment (2002) occurred immediately after the official ruling of unitary status (2001).

A similar district with a similar history yields a quite different sequence of dates. Winston-Salem/Forsyth, another county-wide district in North Carolina, operated a district-wide busing plan much like Charlotte's beginning in 1971, making its schools, like Charlotte's, very balanced. The district was declared unitary soon thereafter, in 1974, but continued nevertheless to operate its desegregation plan. In 1995 a newly elected school board voted to adopt a new approach to student assignment based, like Charlotte's, on parental choice. The plan divided the district into eight zones and would, when fully implemented, give each elementary and middle

\footnotetext{
${ }^{21}$ Website of the Charlotte-Mecklenburg Schools, www.cms.k12.nc.us/discover/narrative.asp, last visited 1/31/03.
} 
school a unique theme and allow parents to choose their children's school from among those within their own geographic zone. Although the school board expressed a wish that the resulting enrollment patterns would not produce large racial disparities across schools (in the form of a guideline that no school would deviate by more than 20 percentage points from the district's overall nonwhite percentage), no controls were put in place to limit parental choices. Indeed, the plan did lead to racial disparities among schools, which sparked complaints. After investigating these complaints, the Office for Civil Rights, in light of the Fourth Circuit decisions disallowing the use of race in assignment, officially gave its blessing to the plan in 2000, after the district pledged to create several district-wide magnet schools. ${ }^{22}$ The resulting measure of racial isolation, like Charlotte's, showed increases. The percentage of black students attending 90$100 \%$ minority schools in the district rose from $6 \%$ in 1995 to $22 \%$ in 2001 and to $23 \%$ in 2003.

But unitary status has not always meant handing a district a free pass, as might be inferred from these two examples from North Carolina. To be sure, in some cases a court's declaration that a district is unitary has been by all appearances an official blessing with few strings attached. The unitary declarations covering such districts as Oklahoma City in 1991, Chatham County (Savannah) in 1994, DeKalb County (suburban Atlanta) in 1996, Muscogee County (Columbus, GA) in 1997, and the Florida districts of Dade (Miami), Duval (Jacksonville), and Hillsborough (Tampa) in 2001 were more or less unconditional terminations of formal, continuing oversight of a desegregation plan. In these cases, unitary status meant that the court had formally washed its hands of further involvement in the details of student assignment and would instead merely stand

${ }^{22}$ Dawn Ziegenbalg, "Civil-Rights Inquiry into Schools Ending; No Major Redistricting Changes Expected," Winston-Salem Journal, January 7, 2000, p. A1; telephone conversation with Doug Punger, attorney for the Winston-Salem/Forsyth School Board, May 15, 2003. 
by to adjudicate any new complaint alleging racial discrimination. ${ }^{23}$ But in more than a few instances, unitary status has been granted only with strings attached. In these cases, unitary status was merely one component of a broader consent decree or other agreement in which the district commits itself to certain practices for some period. Nor do unitary declarations always coincide with the end of court supervision. Five examples serve to illustrate the varied meanings of unitary status.

First, Nashville-Davidson was ruled unitary in 1998, but only as part of a negotiated agreement that allowed the district to replace its cross-district busing plan and the accompanying racial goals for schools with a plan that allowed students to choose neighborhood schools or magnets but also obligated the district to spend some $\$ 200$ million over the following five years on construction and renovation of schools, many in predominantly black neighborhoods. ${ }^{24}$ Second, in Lee County (FL), a federal judge declared the district unitary in 1999, but did not end supervision until 2004. And these declarations were made only after the school district agreed to

${ }^{23}$ To illustrate, the decision in Muscogee County stated: "The district court's conclusions that the school board has eliminated the vestiges of de jure segregation as far as practicable and that the school board has shown a good faith commitment to and compliance with the desegregation plan were not clearly erroneous. Accordingly, we affirm the district court's final dismissal and declaration that the school board has attained unitary status." Lockett v. Muscogee Board of Education, 111 F.3d 839 (1997). Other references are: Oklahoma City: Dowell ex rel. Dowell v. Board of Educ., 778 F.Supp. 1144 (1991); Chatham County: US and Stell v. SavannahChatham County Board of Education, 860 F. Supp. 1563 (1994); DeKalb County: Mills v. Freedman, 942 F. Supp. 1449 (1996); Dade County: "Miami District Declared Unitary," Education Week, July 11, 2001; Duval: NAACP v. Duval County, 273 F.3d 960 (2001); Hillsborough : Manning v. Board of Public Instruction of Hillsborough County, 244 F.3d 927, (2001). The Dade County decision allowed the district to maintain race conscious programs until 2002.

${ }^{24}$ Kathleen Kennedy Manzo, "Curtain Falls on Desegregation Era in Nashville," Education Week, October 7, 1998; http://www.edweek.org/ew/vol-18/06deseg.h18, last visited $7 / 6 / 04$. 
consult with a Unitary School System Advisory Committee regarding certain future decisions, including changes in its student assignment plan and school opening or closings. The school district also committed itself to continuing a school choice plan that would keep minority populations in the bulk of its schools within 20 percentage points of the system average. ${ }^{25}$ Third, Pinellas County (FL) was declared unitary by a federal district court in 2000, but only subject to the terms of a negotiated settlement that called for a seven-year transition from an existing attendance plan utilizing magnet schools and assignments designed to achieve racial balance to a choice plan that would eventually be unconstrained by racial controls. ${ }^{26}$

Fourth, as part of a settlement in 2003, the Fulton County (GA) school district agreed to continue its longstanding minority-to-majority transfer policy for nine years and to examine enrollments in advanced placement and foreign language courses in its predominantly black southern schools (Fulton Co., p.6). Fifth, a federal court's unitary declaration for East Baton Rouge was similarly made subject to an agreement, covering in this case the succeeding four school years. This agreement requires the district to continue its existing system of magnet schools, specifying a target racial composition of 55\% black for them and appointing an independent overseer for the program, continue and actively recruit for its majority-to-minority

\footnotetext{
${ }^{25}$ Dave Breitenstein, “'Children Have Changed Our Community” Lee Official Says," Naples Daily News, May 16, 2004; http://www.naplesnews.com, last visited 7/6/04.

${ }^{26}$ For the 2000/01 to 2002/03 years, the previous assignment plan would be continued; for the 2003/04 to 2006/07 years, a controlled choice plan would be implemented whereby schools would have no more than $42 \%$ black enrollments. U.S. District Court, Case No. 8:64CV-98-T-23B. http://www.pinellas.k12.fl.us/usi/htm/FinalOrder.pdf School Board of Pinellas County, Choice Plan, October 24, 2000 http://www.pinellas.k12.fl.us/USI/choiceplan.html
} 
transfer policy, with rules for transfers stated in terms of specific racial compositions, provide free transportation for both of these programs, attempt to further desegregation in redrawing attendance lines, make additional expenditures for certain schools, and continue pre-kindergarten programs. ${ }^{27}$ A sixth example, though not technically a unitary declaration, was the ending of federal oversight over the St. Louis district in 1999. There the court made this withdrawal subject to a detailed settlement, by which the district agreed to continue operating its group of magnet schools and the state agreed to continue funding the city-to-suburb transfer voluntary busing program and to finance the construction and renovation of schools in the district. ${ }^{28}$

Thus unitary status, or the ending of judicial oversight of a desegregation plan, has meant different things in different districts at different times. Nor can it be assumed that districts never subject to any desegregation order, such as Montgomery County, Maryland or Cumberland County, North Carolina, are not influenced by federal court rulings. As noted above, Montgomery County was the district to which one of the Fourth Circuit rulings regarding raceconscious school assignments applied. For districts not under a specific court order, school boards must worry about potential law suits or federal sanctions arising from the 1964 Civil Rights Act, by which the federal government can cut off funding to discriminating districts. To

${ }^{27}$ For magnet schools the agreement specified a target racial composition of $55 \%$ black and $45 \%$ nonblack. It give preference to students nearby and who attend racially identifiable schools. "Final Settlement Agreement," U.S. District Court for the Middle District of Louisiana, Civil Action 56-1662-D-M3, July 16, 2003. See also website for U.S. Attorney, http://www.usdoj.gov/usao/lam/press/press0204.html.

${ }^{28}$ Hendrie, Caroline. 1999. "Settlement Ends St. Louis Desegregation Case." Education Week March 24, 1999. (http://www.edweek.org/ew/vol-18/28louis.h18) 
recap, then, there is no one-to-one connection between unitary status and freedom to return to de facto segregation.

Because of the importance attached to unitary status in discussions of resegregation, we have endeavored to ascertain for each of the 100 districts analyzed in the current paper whether the district has been deemed unitary and, if so, when that declaration was made. For this purpose, we have drawn on a variety of sources, including published court decisions, district web pages, and news reports. ${ }^{29}$

\section{The Impact of Court Rulings}

We focus here on two main aspects of judicial rulings: the declaration of unitary status and whether or not a district is located in the Fourth Circuit and, hence, subject to that circuit's admonitions to eschew the use of race in student assignments. We begin with some simple trend analysis and then turn to a more complete multivariate model that permits us to isolate the effects of the court decisions from other changes.

\section{Role of Fourth Circuit Decisions}

The bottom panel of Table 2 above provides some initial insight into the role of the Fourth Circuit decisions, with attention to our two preferred measures of segregation, one that measures racial isolation and one that measures racial imbalance. If, as Boger (2000) argues, the admonitions in that circuit against race-based student assignments had teeth, one might expect

${ }^{29}$ The years in which districts in our sample were declared unitary are listed in Appendix Table 1. A detailed summary of the sources used to make these designations is available at http://www.pubpol.duke.edu/people/faculty/clotfelter/. 
segregation to rise more over the period in the Fourth Circuit than in other federal circuits. Indeed, the two districts with the largest increases in the segregation index over the period, Charlotte-Mecklenburg and Winston-Salem/Forsyth, are both in the Fourth Circuit. For the circuit as a whole the table entries confirm that pattern. During the 10-year period, racial isolation increased in all of the circuits identified, but it grew far faster in the Fourth Circuit (57 percent) than in the other circuits (10 to 33 percent). With respect to racial imbalance, as measured by the gap-based segregation index, only the Fourth Circuit exhibited an increase and quite a substantial one at that - in its segregation index. In each of the other relevant federal court circuits, schools became less racially unbalanced over the 10 -year period. Thus we have some initial evidence that the rulings in the Fourth District exacerbated segregation.

\section{Unitary status}

Our initial trend analysis of unitary status leads to a different conclusion. For this purpose we compared the trend in the proportion of students attending schools in districts deemed to unitary to the trends in segregation indexes. The bottom panel of Table 1 shows that by 2003 a far higher percentage of students in our sample districts were attending schools in districts declared unitary than in 1993, and Figure 6 shows how the number of districts so designated increased year by year. Between 1993 and 1999, the fraction of districts deemed unitary, weighted by enrollment, increased gradually, from about $12 \%$ to just over $20 \%$. Starting in 1999 and continuing over the next three years, the rate of growth increased markedly, with the (weighted) share of districts with unitary status increasing from just over $20 \%$ to $45 \%$. This clearly nonlinear pattern contrasts with the smoother trends exhibited by segregation indices in 
Figure 1. Were unitary status responsible for a large portion of the increases in segregation, we would expect a break in trend coinciding with or following closely the surge in unitary status declarations after 1999. But the trends in segregation are not consistent with this supposition; indeed, with one exception our measures of segregation are not even rising. At first blush, therefore, we find little reason to blame judicial decisions relating to unitary status for any rise in segregation levels. This conclusion must be tempered, however, considering that the counterfactual is not clearly specified and the possibility that any effects of unitary status might occur with a substantial lag. For these reasons we turn to a more comprehensive multivariate analysis.

Multivariate Regression Analysis

Beyond enabling us to simultaneously examine the impact of multiple explanatory factors, the analysis in this section expands on the simple examination of trends above by introducing cross-sectional variation in segregation. As Figures 4 and 5 indicate, districts differed widely in their experiences over time.

The ordinary least squares regression estimates in Table 3 use three segregation measures as dependent variables: a racial isolation measure (the fraction of black students attending schools with nonwhite shares between 90 and 100\%) and two racial imbalance measures (the gap-based measure of segregation between whites and nonwhites and the entropy index). ${ }^{30}$ The

${ }^{30}$ The sample covers years from 1993/94 to 2003/04, with these exceptions necessitated by missing data in the Common Core of Data. Data for Georgia districts in 1992/93 were missing, which necessitated omitting observations in 1993/94, owing to the use of lagged variables. School-level data for Tennessee districts were missing in 1997/98 and 1999/2000 to 2002/03, making it impossible to calculate segregation measures for those years. 
specifications in columns (1), (2) and (3) include only year fixed effects, to illustrate the overall time trend in each segregation measure. In all three columns, none of the coefficients on individual year indicator variables is statistically distinguishable from zero, indicating that we cannot reject the hypothesis that differences in segregation between 1993 and any subsequent year are due to random fluctuations in the data. ${ }^{31}$ In general, the coefficients confirm the patterns shown in Figure 1: the racial isolation measure trends upward over time, while there is no discernible trend in either measure of racial imbalance.

In columns (4) through (6), we add a number of controls for school district characteristics, including an indicator variable for whether a district had been declared unitary by a particular year. Comparison of columns (1) and (4) reveals that this set of control variables is sufficient to explain the upward trend in racial isolation over time. The only statistically significant coefficient on a time-varying variable in this regression pertains to the lagged nonwhite share of enrollment in the district. As suggested by much of the simple evidence presented above, the best explanation for the increasing proportion of black students attending overwhelmingly nonwhite schools is the relative increase in the nonwhite, non-black population in the districts they attend.

We find significant associations between segregation and several time-invariant control variables. Physically large districts tend to be more segregated, holding enrollment levels constant. This may reflect the desire in lower density districts to reduce overall transportation costs by operating more schools. Operating more schools, in turn, enables greater separation of

${ }^{31}$ Nor do F-tests of the coefficients in columns 1 and 2 allow us to reject the hypothesis that either racial isolation or racial imbalance was the same in all years. 
students by race. Districts with a greater proportion of nonwhite students also tend to be more segregated by either measure. Such a pattern would occur, for example, if "white flight" tends to occur when the nonwhite share in a white student's school exceeds a certain threshold, and districts take explicit or implied actions to ensure that this threshold is not exceeded (Clotfelter, Ladd and Vigdor 2003).

Coefficients on judicial circuit indicator variables show no evidence of persistently higher segregation levels in the Fourth Circuit. In fact, school districts in the Fourth Circuit have the lowest proportion of black students attending 90-100\% nonwhite schools, controlling for other factors. It is important to note that this coefficient tests only for a permanent difference in segregation levels across appeals court circuits. In Table 2 above, we found suggestive evidence of differential trends in segregation across circuits. We test the hypothesis of differential trends in a regression framework below.

As shown in column (4), unitary status is not significantly related to racial isolation. In contrast, we find evidence in columns (5) and (6) that districts covered by a unitary status ruling tend to have higher degrees of racial imbalance across schools. The statistically significant positive coefficient in (5) indicates that such districts tend to have white-nonwhite segregation indices almost four percentage points, roughly one-third of a standard deviation, higher than otherwise equivalent districts without unitary status. The estimated effect of unitary status on the entropy measure is also statistically significant, but smaller, roughly one-fifth of a standard deviation. Whether these findings represent a causal effect of unitary status or simply a positive correlation between being unitary and having other factors that raise segregation is impossible to say. 
Table 4 presents results from two alternative specifications that expand the set of control variables to include some related to time. To examine the possibility that the Fourth Circuit's prohibition of race-conscious school assignments might have led to greater segregation over time, in columns (1) through (3) we interact the Fourth Circuit indicator with a linear time trend. The main linear time trend effect in this specification is subsumed by the year fixed effects. The results in columns (2) and (3) show that racial imbalance in school districts within the Fourth Circuit increased significantly over time relative to similar districts served by other federal circuits. A similar result does not hold when the racial isolation index is substituted for the measure of imbalance (column (1)). Because it was not until 1999 that the Fourth Circuit Court of Appeals handed down their decisions prohibiting race-conscious student assignments, one would not expect any effort before that year except to the extent the decision was anticipated. When we added additional variables to allow for a change in circuit effect in that year, however, we obtained statistically insignificant estimated coefficients, leaving us unpersuaded that these decisions were responsible in any increase in segregation by the end of our sample period.

Columns (4) through (6) test for a potential lagged impact of unitary status rulings, by replacing the single unitary status indicator variable with a series of four mutually exclusive indicators, which indicate whether a district was declared unitary in the year of observation, one year earlier, two years earlier, or three or more years earlier. As in previous specifications, there is no significant impact of unitary status on our measure of racial isolation, shown in column (4). The last two regressions in this table, however, show significant evidence of a latency period of at least three years between the declaration of unitary status and a significant impact on our 
measure of racial imbalance. In contrast, more recent unitary declarations are not associated with higher levels of segregation.

There are two reasons to be cautious in interpreting the unitary status results in Tables 3 and 4. First, we have only a limited number of district-specific control variables available. The positive effect of unitary status in Table 3 and for unitary status after three years in Table 4 are identified largely by comparing districts that have had unitary status for the duration of our panel to districts that never received unitary status. Differences between these types of districts could generate significant variation in racial imbalance even in the absence of court rulings. A second reason is the potential for serial correlation in the outcome measure of interest. In a panel framework such as ours, we must be attuned to the possibility of spurious difference-indifference estimates rooted in serial correlation in outcomes.

To address both of these concerns, we re-estimated equations (4)-(6) in Tables 3 and 4 using district fixed effects. By so doing, we restricted our ability to observe an association between segregation and unitary status to those districts in which unitary status actually changed during the sample period or shortly before. These fixed-effects regressions appear in Table 5. As in the two previous tables, equation (1) shows that the measure of racial isolation is unrelated to unitary status. Equations (2) and (3) in the table show that the addition of district fixed effects greatly attenuates the association with unitary status, the estimated coefficient being about half the size of the corresponding coefficient in the equation without fixed effects and being statistically significant only in equation (3). The second set of equations allows for the same type of lagged effect of unitary status as shown in Table 4. As in those previous equations, there is no statistically significant association between any of the three measures of segregation and unitary 
status declarations in the current year, in the previous year, or in the year before that. However, for all three of the measures unitary status declarations three or more years before do show a statistically significant association with the designated measures of segregation. These equations suggest again that unitary status is associated with increased segregation, but the effect appears only with a lag. These findings are broadly consistent with those of Lutz (2004). Employing a model that allows for more flexibility in the time pattern of effects, he finds that the end of courtordered desegregation in a district was followed by a gradual linear increase in segregation. ${ }^{32}$

This delayed response to unitary status is very much in keeping with the common tendency for courts to attach conditions when declaring school districts to be unitary. As our review of specific cases indicated, it was typical for the end of court supervision to be accompanied by an agreement by the school district to continue certain specified practices for a period of time that would have the effect of maintaining some degree of racial balance in enrollments. Only when the period covered by those agreements came to an end were districts really free to chart their own course regarding student assignments, including the return to neighborhood school assignments and hence to racially imbalanced schools.

\section{Conclusion}

Analysis of the 100 largest districts in the South and Border regions shows unmistakably that public schools in these regions have become more nonwhite over the past ten years. They have not, however, witnessed a systematic increase in the segregation of white students. Rather,

${ }^{32}$ Lutz's (2004) paper differs in several other ways from ours, including the use of slightly different measures of segregation and a sample that is larger and which includes districts outside of the South and Border states. 
black and white students alike now attend schools with greater proportions of Hispanic, Asian, and students of other races. This development creates the impression of increasing segregation when segregation is measured by one widely-used index - the proportion of blacks attending 90$100 \%$ nonwhite schools - but the rise in this measure is the result of demographic change rather than any growing racial imbalance among schools. As a consequence of the increasing racial diversification of American schools, this particular measure of racial isolation may have lost much of its meaning as a measure of racial segregation. All of the other school segregation measures examined in this paper point to a different conclusion - that the average level of segregation in large Southern school districts has not changed much over the last decade.

Averages are not the whole story, however. One of our main objectives in this paper has been to investigate the effect of unitary status declarations by federal courts. A fear has been that such a declaration essentially gives a district permission to base school assignments solely on neighborhood residence, which will tend to make schools more racially segregated, given the segregation in existing housing patterns. The case of Charlotte-Mecklenburg - where a neighborhood assignment plan and resegregation did indeed follow quickly on the heels of a unitary declaration - appears to offer graphic justification for this fear. In our regression analysis examining the experience of 100 districts over 10 years, we found that unitary status is in fact associated with increased white-nonwhite segregation, in the sense of racial imbalance. Our estimates suggest that, for the districts serving nearly half of all students in the sample where courts have issued unitary status declarations, segregation levels were higher than in other districts. But this result is largely driven by higher segregation rates in districts that were declared unitary before 1993. For only one of our two measures of racial imbalance do we observe any 
effect of unitary status declarations during our sample period, and the size of that effect is only about as half as large as that implied by previous specifications. The absence of a contemporaneous effect could be due to the tendency of such declarations to be accompanied by agreements that placed constraints on the freedom of school districts to return to neighborhood school assignment or by other factors that delay the effect. We also find that segregation as racial imbalance increased in districts governed by the Fourth Circuit, the judicial circuit that has most prominently ruled against racially-conscious student assignments, but that effect is not restricted to the period after the relevant rulings.

In all but one of the regressions explaining the percentage of blacks in 90-100\% nonwhite schools, neither unitary status nor Fourth Circuit jurisdiction has any explanatory power, suggesting, as above, that this measure is driven largely by the steady increase in the nonwhite percentage in the public school population, not by increases in racial imbalance. Only in the fixed-effect regression using lags is this measure associated at standard levels of statistical significance with unitary status.

A final caveat is worth re-emphasizing. In this paper, we base our measures of segregation and racial isolation on disparities between schools in districts. Our analysis measures neither disparities between districts nor disparities within schools. Nor do our measures account for segregation arising from private school enrollment. Our previous research suggests that the first two of these sources of segregation is generally quite important and that the third can be significant in some localities. ${ }^{33}$ Although it considers only segregation across schools in public school districts, however, the current paper is quite relevant to the current

\footnotetext{
${ }^{33}$ See Clotfelter, Ladd, and Vigdor (2003) and Clotfelter (2004).
} 
concern over resegregation and the role of federal court rulings, for it finds some justification for fears that the two are linked. Participants in these debates need to be wary of the evidence they cite, however, especially when using statistics that reflect racial isolation rather than racial imbalance. 


\section{References}

Armor, David J. 1995. Forced Justice: School Desegregation and the Law. New York: Oxford University Press.

Boger, John Charles, "Willful Colorblindness: The New Racial Piety and the Resegregation of Public Schools," North Carolina Law Review 78 (September 2000), 17191796.

Clotfelter, Charles T. 1999. "Public School Segregation in Metropolitan Areas," Land Economics 75 (November), 487-504.

Clotfelter, Charles T. 2004. After Brown: The Rise and Retreat of School Desegregation. Princeton, N.J.: Princeton University Press.

Clotfelter, Charles T., Helen F. Ladd, and Jacob L. Vigdor. 2003. "Segregation and Resegregation in North Carolina's Public School Classrooms," North Carolina Law Review 81 (May), 1463-1511.

"The Effects of Segregation and the Consequences of Desegregation: A Social Science Statement," Minnesota Law Review 37 (1953), 427-439.

Frankenberg, Erica and Chungmei Lee. 2002. "Race in American Public Schools: Rapidly Resegregating School Districts," The Civil Rights Project, Harvard University, August.

Frankenberg, Erica, Chungmei Lee, and Gary Orfield, A Multiracial Society with Segregated Schools: Are We Losing the Dream? Civil Rights Project, January 2003.

Fulton County Schools. 2003. Annual Report to the Community. http://www.fulton.k12.ga.us/ez/detail.asp?q=160, 7/6/04.

Glaeser, E.L. and J.L. Vigdor. "Racial Segregation: Promising News.” in Redefining Urban \& Suburban America: Evidence from Census 2000, Volume I, B. Katz and R. Lang, eds., pp.211-234. Brookings Institution Press, 2003.

Iceland, John. 2002. "Beyond Black and White: Metropolitan Residential Segregation in Multi-Ethnic America," paper presented at the American Sociological Association meetings, August. www.census.gov/hhes/www/housing/resseg/pdf/beyond_black_and_white.pdf, last visited 11/27/04 
Logan, John. 2004. "Resegregation in American Public Schools? Not in the 1990s." Report, Lew Mumford Center for Comparative Urban and Regional Research, University at Albany, April 26.

Lutz, Byron F., "After Brown: The Effects of the End of Court-Ordered Desegregation," unpublished paper, MIT Department of Economics, November 2004.

Massey, Douglas S. and Nancy A. Denton, "The Dimensions of Residential Segregation," Social Forces 67 (December 1988), 281-315.

NAACP Legal Defense and Educational Fund, Inc., Herschel Lee Johnson, ed. 2000 Annual Report. New York: NAACP. http://www.naacpldf.org/content/pdf/pubs/annual/2000 Annual Report.pdf (7/7/2004).

Orfield, Gary, and Susan E. Eaton. 1996. Dismantling Desegregation: The Quiet Reversal of Brown v. Board of Education. New York: The New Press.

Orfield, Gary and Nora Gordon, "Schools More Separate: Consequences of a Decade of Resegregation,” unpublished paper, Harvard University, July 2001.

Orfield, Gary and Chungmei Lee. 2004. "Brown at 50: King's Dream or Plessy's Nightmare?" The Civil Rights Project, Harvard University, January.

Orfield, Gary and Frank Monfort. 1992. Status of School Desegregation: The Next Generation. Cambridge, MA: Metropolitan Opportunity Project, Harvard University. March.

Theil, Henri. 1972. Statistical Decomposition Analysis. Amsterdam: North-Holland Publishing Co.

Cases

Board of Education of Oklahoma v. Dowell, 498 U.S. 237 (1991).

Brown v. Board of Education of Topeka, 347 U.S. 483 (1954).

Capacchione v. Charlotte-Mecklenburg Schools, 57 F. Supp. 2 d 228 (W.D.N.C. 1999).

Comfort v. Lynn School Committee, 28 F. Supp. 2d 328 (D. Mass. 2003).

Eisenberg v. Montgomery County Public Schools, 197 F.3d 123 ( ${ }^{\text {th }}$ Cir. 1999).

Freeman v. Pitts, 503 U.S. 467 (1992).

Green v. County School Board of New Kent County, 391 U.S. 430 (1968).

Grutter v. Bollinger, 71 U.S.L.W. 4498 (2003).

McFarland v. Jefferson Co. Public Schools, 330 F. Supp. 2d 834 (W.D. Ky. 2004).

Parents Involved in Community Schools v. Seattle School District, No. 1, 377 F. 3d 949 (9 $9^{\text {th }}$ Cir. 2004)

Swann v. Charlotte-Mecklenburg Board of Education, 402 U.S. 1 (1971). 
Tuttle v. Arlington County School Board, 195 F.3d 698 (4 $4^{\text {th }}$ Cir. 1999).

G:Iteachqlctcdocs\PUBrown\PUBrowndraft20905.wpd 
Table 1. Mean Values of Variables, Weighted by Enrollment, 100 Districts

\begin{tabular}{|c|c|c|c|c|}
\hline \multirow[b]{2}{*}{ Variable } & \multicolumn{2}{|c|}{ 1993/94 } & \multicolumn{2}{|c|}{$2003 / 04$} \\
\hline & Mean & Std. dev. & Mean & Std. dev. \\
\hline \multicolumn{5}{|l|}{ Segregation } \\
\hline$\% \mathrm{~B}$ in $90-100 \% \mathrm{NW}$ schools & 0.269 & 0.303 & 0.341 & 0.331 \\
\hline$\% \mathrm{~B}$ in $90-100 \% \mathrm{~B}$ schools & 0.170 & 0.233 & 0.153 & 0.231 \\
\hline Black-black exposure & 0.464 & 0.245 & 0.464 & 0.237 \\
\hline White-nonwhite segregation & 0.201 & 0.120 & 0.200 & 0.101 \\
\hline Dissimilarity index (W-NW) & 0.413 & 0.151 & 0.426 & 0.142 \\
\hline Entropy & 0.197 & 0.121 & 0.195 & 0.103 \\
\hline \multicolumn{5}{|l|}{ District characteristics } \\
\hline Average district enrollment & 88,908 & 66,188 & 107,790 & 82,082 \\
\hline Average white enrollment & 37,352 & 24,448 & 36,713 & 26,083 \\
\hline Percent nonwhite & 0.503 & 0.251 & 0.601 & 0.225 \\
\hline$\% \mathrm{NW}: 0$ to less than $25 \%$ & 0.170 & 0.429 & 0.048 & 0.465 \\
\hline$\% \mathrm{NW}$ : from 25 to less than $50 \%$ & 0.416 & 0.493 & 0.324 & 0.468 \\
\hline$\% \mathrm{NW}$ : from 50 to less than $75 \%$ & 0.141 & 0.349 & 0.337 & 0.473 \\
\hline$\% \mathrm{NW}$ : from 75 to $100 \%$ & 0.272 & 0.445 & 0.291 & 0.454 \\
\hline Average district land area* & 615 & 543 & 639 & 549 \\
\hline \multicolumn{5}{|l|}{ Type } \\
\hline Central city* & 0.248 & 0.483 & 0.208 & 0.488 \\
\hline Consolidated* & 0.417 & 0.493 & 0.426 & 0.494 \\
\hline Suburban* & 0.335 & 0.472 & 0.367 & 0.482 \\
\hline \multicolumn{5}{|l|}{ Region } \\
\hline Border state* & 0.159 & 0.366 & 0.143 & 0.350 \\
\hline Southern state* & 0.841 & 0.366 & 0.857 & 0.350 \\
\hline \multicolumn{5}{|l|}{ Judicial characteristics } \\
\hline Unitary & 0.121 & 0.326 & 0.446 & 0.497 \\
\hline Fourth Circuit* & 0.241 & 0.415 & 0.244 & 0.407 \\
\hline Fifth Circuit* & 0.272 & 0.445 & 0.260 & 0.439 \\
\hline Eleventh Circuit* & 0.374 & 0.484 & 0.402 & 0.490 \\
\hline All other federal circuits* & 0.113 & 0.316 & 0.094 & 0.292 \\
\hline Unitary status before $1993^{*}$ & 0.176 & 0.476 & 0.161 & 0.477 \\
\hline Unitary status in ' 93 - $^{\prime} 03^{*}$ & 0.288 & 0.453 & 0.295 & 0.456 \\
\hline Never became unitary* & 0.535 & 0.499 & 0.544 & 0.498 \\
\hline
\end{tabular}

Source: Common Core of Data, unpublished data from districts, and authors' calculations, for the 100 largest school districts in the South and Border in 2001/02. See Appendix 1A for a list of the districts.

* Difference across years are due to difference in weights used in the averages.

$11 / 30 / 04$ 
Table 2. Mean Values of Selected Measures, for Selected Categories, 100 Districts

\begin{tabular}{|c|c|c|c|c|c|c|c|c|c|}
\hline & & & & Racia & $\begin{array}{l}\text { tion: } \\
\text { W schools }\end{array}$ & $\begin{array}{l}\text { Racial ir } \\
\text { W-NW s }\end{array}$ & $\begin{array}{l}\text { ance: } \\
\text { gation }\end{array}$ & & \\
\hline Sample & $\begin{array}{c}\text { Number of } \\
\text { districts }\end{array}$ & $\begin{array}{c}\text { Average growth } \\
\text { rate of whites } \\
2003-1993 \\
\end{array}$ & $\begin{array}{c}1993 / 94 \\
\% \mathrm{NW}\end{array}$ & $1993 / 94$ & $2003 / 04$ & $1993 / 94$ & $2003 / 04$ & $1993 / 94$ & $2003 / 04$ \\
\hline Full sample & 100 & -0.017 & 0.503 & 0.269 & 0.341 & 0.201 & 0.200 & 0.197 & 0.195 \\
\hline$\underline{\text { Region }}$ & & & & & & & & & \\
\hline Border & 15 & -0.026 & 0.517 & 0.293 & 0.370 & 0.228 & 0.218 & 0.193 & 0.192 \\
\hline South & 85 & -0.015 & 0.501 & 0.264 & 0.336 & 0.196 & 0.197 & 0.218 & 0.213 \\
\hline Type & & $* * *$ & $* * *$ & $* * *$ & $* * *$ & $* * *$ & * & $* * *$ & $* * *$ \\
\hline Central city & 22 & -0.044 & 0.771 & 0.585 & 0.660 & 0.268 & 0.244 & 0.304 & 0.272 \\
\hline Consolidated & 36 & -0.007 & 0.448 & 0.215 & 0.299 & 0.196 & 0.195 & 0.180 & 0.191 \\
\hline Suburban & 42 & -0.013 & 0.374 & 0.101 & 0.210 & 0.158 & 0.180 & 0.140 & 0.156 \\
\hline \% nonwhite, 93/94 & & $* * *$ & $* * *$ & $* * *$ & $* * *$ & $* * *$ & & $* * *$ & \\
\hline $0-25 \%$ & 24 & 0.008 & 0.185 & 0.019 & 0.034 & 0.122 & 0.159 & 0.121 & 0.198 \\
\hline $25-50 \%$ & 39 & -0.004 & 0.371 & 0.121 & 0.200 & 0.190 & 0.202 & 0.149 & 0.222 \\
\hline $50-75 \%$ & 19 & -0.034 & 0.602 & 0.258 & 0.399 & 0.208 & 0.214 & 0.183 & 0.192 \\
\hline $75-100 \%$ & 18 & -0.052 & 0.853 & 0.655 & 0.817 & 0.264 & 0.220 & 0.326 & 0.121 \\
\hline$\underline{\text { Federal Circuit }}$ & & $* *$ & $* *$ & $* *$ & & & & & \\
\hline Fourth & 24 & -0.010 & 0.413 & 0.133 & 0.210 & 0.173 & 0.203 & 0.152 & 0.166 \\
\hline Fifth & 32 & -0.030 & 0.629 & 0.362 & 0.431 & 0.191 & 0.181 & 0.211 & 0.190 \\
\hline Eleventh & 32 & -0.009 & 0.466 & 0.262 & 0.351 & 0.211 & 0.203 & 0.207 & 0.206 \\
\hline All others & 12 & -0.031 & 0.503 & 0.353 & 0.390 & 0.255 & 0.228 & 0.230 & 0.235 \\
\hline
\end{tabular}

Source: Common Core of Data, unpublished data from districts, and authors' calculations, for the 100 largest school districts in the South and Border in 2001/02. See Appendix 1A for a list of the districts. Means are weighted by district enrollment.

*; **; ***: Means are different from each other within the category at $10 \%$ level; $5 \%$ level and $1 \%$ level, respectively. 
Table 3. Regressions Explaining Segregation and Racial Isolation, Pooled Sample

\begin{tabular}{|c|c|c|c|c|c|c|}
\hline Independent variable & $\begin{array}{c}(1) \\
\% B \text { 90-100\% NW }\end{array}$ & $\begin{array}{c}(2) \\
\text { W-NW Seg. }\end{array}$ & $\begin{array}{c}(3) \\
\text { Entropy }\end{array}$ & $\begin{array}{c}(4) \\
\% \mathrm{~B} 90-100 \% \mathrm{NW}\end{array}$ & $\begin{array}{c}(5) \\
\text { W-NW seg. }\end{array}$ & $\begin{array}{c}\text { (6) } \\
\text { Entropy }\end{array}$ \\
\hline \multicolumn{7}{|l|}{ Years (omitted 1993) } \\
\hline 1994 & $\begin{array}{c}0.008 \\
{[0.047]}\end{array}$ & $\begin{array}{c}0.001 \\
{[0.016]}\end{array}$ & $\begin{array}{l}-0.000 \\
{[0.016]}\end{array}$ & $\begin{array}{c}0.001 \\
{[0.023]}\end{array}$ & $\begin{array}{c}0.008 \\
{[0.015]}\end{array}$ & $\begin{array}{c}0.003 \\
{[0.012]}\end{array}$ \\
\hline 1995 & $\begin{array}{c}0.015 \\
{[0.047]}\end{array}$ & $\begin{array}{c}0.001 \\
{[0.016]}\end{array}$ & $\begin{array}{c}0.001 \\
{[0.016]}\end{array}$ & $\begin{array}{c}-0.002 \\
{[0.023]}\end{array}$ & $\begin{array}{c}0.007 \\
{[0.015]}\end{array}$ & $\begin{array}{c}0.001 \\
{[0.012]}\end{array}$ \\
\hline 1996 & $\begin{array}{c}0.022 \\
{[0.047]}\end{array}$ & $\begin{array}{c}0.002 \\
{[0.016]}\end{array}$ & $\begin{array}{c}0.004 \\
{[0.016]}\end{array}$ & $\begin{array}{l}-0.008 \\
{[0.023]}\end{array}$ & $\begin{array}{c}0.007 \\
{[0.015]}\end{array}$ & $\begin{array}{c}0.003 \\
{[0.012]}\end{array}$ \\
\hline 1997 & $\begin{array}{c}0.026 \\
{[0.047]}\end{array}$ & $\begin{array}{l}-0.003 \\
{[0.016]}\end{array}$ & $\begin{array}{l}-0.004 \\
{[0.016]}\end{array}$ & $\begin{array}{l}-0.011 \\
{[0.023]}\end{array}$ & $\begin{array}{c}0.002 \\
{[0.015]}\end{array}$ & $\begin{array}{l}-0.004 \\
{[0.012]}\end{array}$ \\
\hline 1998 & $\begin{array}{c}0.036 \\
{[0.046]}\end{array}$ & $\begin{array}{c}0.003 \\
{[0.016]}\end{array}$ & $\begin{array}{c}0.002 \\
{[0.016]}\end{array}$ & $\begin{array}{l}-0.007 \\
{[0.023]}\end{array}$ & $\begin{array}{c}0.008 \\
{[0.015]}\end{array}$ & $\begin{array}{l}-0.000 \\
{[0.012]}\end{array}$ \\
\hline 1999 & $\begin{array}{c}0.040 \\
{[0.047]}\end{array}$ & $\begin{array}{l}-0.002 \\
{[0.016]}\end{array}$ & $\begin{array}{l}-0.002 \\
{[0.016]}\end{array}$ & $\begin{array}{l}-0.011 \\
{[0.023]}\end{array}$ & $\begin{array}{c}0.003 \\
{[0.015]}\end{array}$ & $\begin{array}{c}-0.005 \\
{[0.012]}\end{array}$ \\
\hline 2000 & $\begin{array}{c}0.047 \\
{[0.047]}\end{array}$ & $\begin{array}{c}-0.001 \\
{[0.016]}\end{array}$ & $\begin{array}{c}-0.002 \\
{[0.016]}\end{array}$ & $\begin{array}{c}-0.011 \\
{[0.023]}\end{array}$ & $\begin{array}{c}0.002 \\
{[0.015]}\end{array}$ & $\begin{array}{c}-0.007 \\
{[0.012]}\end{array}$ \\
\hline 2001 & $\begin{array}{c}0.056 \\
{[0.046]}\end{array}$ & $\begin{array}{c}-0.002 \\
{[0.016]}\end{array}$ & $\begin{array}{c}-0.002 \\
{[0.016]}\end{array}$ & $\begin{array}{c}-0.014 \\
{[0.023]}\end{array}$ & $\begin{array}{c}0.000 \\
{[0.015]}\end{array}$ & $\begin{array}{l}-0.011 \\
{[0.012]}\end{array}$ \\
\hline 2002 & $\begin{array}{c}0.060 \\
{[0.046]}\end{array}$ & $\begin{array}{c}-0.001 \\
{[0.016]}\end{array}$ & $\begin{array}{c}-0.002 \\
{[0.016]}\end{array}$ & $\begin{array}{c}-0.019 \\
{[0.024]}\end{array}$ & $\begin{array}{c}-0.001 \\
{[0.015]}\end{array}$ & $\begin{array}{c}-0.012 \\
{[0.012]}\end{array}$ \\
\hline 2003 & $\begin{array}{c}0.070 \\
{[0.046]}\end{array}$ & $\begin{array}{c}-0.004 \\
{[0.016]}\end{array}$ & $\begin{array}{c}-0.005 \\
{[0.016]}\end{array}$ & $\begin{array}{c}-0.017 \\
{[0.024]}\end{array}$ & $\begin{array}{c}-0.006 \\
{[0.016]}\end{array}$ & $\begin{array}{c}-0.018 \\
{[0.012]}\end{array}$ \\
\hline
\end{tabular}




\begin{tabular}{|c|c|c|c|c|c|c|}
\hline Lagged $\log ($ enrollment $)$ & - & - & - & $\begin{array}{l}-0.005 \\
{[0.011]}\end{array}$ & $\begin{array}{l}-0.001 \\
{[0.007]}\end{array}$ & $\begin{array}{c}0.003 \\
{[0.006]}\end{array}$ \\
\hline $\log ($ land area $)$ & - & - & - & $\begin{array}{c}0.066 * * * \\
{[0.008]}\end{array}$ & $\begin{array}{c}0.039 \\
{[0.005]}\end{array}$ & $\begin{array}{c}0.041 * * * \\
{[0.004]}\end{array}$ \\
\hline Lagged \%NW District & - & - & - & $\begin{array}{c}0.972 * * * \\
{[0.029]}\end{array}$ & $\begin{array}{c}0.157 * * * \\
{[0.019]}\end{array}$ & $\begin{array}{c}0.230 * * * \\
{[0.015]}\end{array}$ \\
\hline \multicolumn{7}{|c|}{ Type (omitted central city) } \\
\hline Consolidated & - & - & - & $\begin{array}{c}-0.158 * * * \\
{[0.019]}\end{array}$ & $\begin{array}{c}-0.039 * * * \\
{[0.012]}\end{array}$ & $\begin{array}{c}-0.076^{* * * *} \\
{[0.010]}\end{array}$ \\
\hline Suburban & - & - & - & $\begin{array}{c}-0.101 * * * \\
{[0.107]}\end{array}$ & $\begin{array}{l}-0.021 * \\
{[0.011]}\end{array}$ & $\begin{array}{c}-0.043 * * * \\
{[0.009]}\end{array}$ \\
\hline \multicolumn{7}{|l|}{$\begin{array}{l}\text { Federal circuit (omitted } \\
\text { Fifth) }\end{array}$} \\
\hline Fourth Circuit & - & - & - & $\begin{array}{c}-0.034 * * \\
{[0.014]}\end{array}$ & $\begin{array}{c}0.007 \\
{[0.009]}\end{array}$ & $\begin{array}{l}-0.005 \\
{[0.007]}\end{array}$ \\
\hline Eleventh Circuit & - & - & - & $\begin{array}{l}0.034 * * \\
{[0.015]}\end{array}$ & $\begin{array}{l}0.023^{* *} \\
{[0.010]}\end{array}$ & $\begin{array}{c}0.020 * * * \\
{[0.008]}\end{array}$ \\
\hline All Others & - & - & - & $\begin{array}{l}0.048^{* *} \\
{[0.019]}\end{array}$ & $\begin{array}{c}0.042 * * * \\
{[0.012]}\end{array}$ & $\begin{array}{c}0.043 * * * * \\
{[0.010]}\end{array}$ \\
\hline Unitary status & - & - & - & $\begin{array}{c}0.015 \\
{[0.013]}\end{array}$ & $\begin{array}{c}0.038^{* * * *} \\
{[0.009]}\end{array}$ & $\begin{array}{c}0.022 * * * \\
{[0.007]}\end{array}$ \\
\hline Observations & 1070 & 1070 & 1070 & 1061 & 1061 & 1061 \\
\hline $\mathrm{R}^{2}$ & .00 & .00 & .00 & .72 & .20 & .41 \\
\hline
\end{tabular}

Note: No GA observations for 2003 due to missing lag of NW\% $11 / 4 / 04$ 
Table 4. Additional regressions specifications, with time trend (Year-1992) variable

\begin{tabular}{|c|c|c|c|c|c|c|}
\hline Independent variable & $\begin{array}{c}(1) \\
\% B \text { 90-100\% NW }\end{array}$ & $\begin{array}{c}(2) \\
\text { W-NW Seg. }\end{array}$ & $\begin{array}{c}(3) \\
\text { Entropy }\end{array}$ & $\begin{array}{c}(4) \\
\% \mathrm{~B} 90-100 \% \mathrm{NW}\end{array}$ & $\begin{array}{c}(5) \\
\text { W-NW seg. }\end{array}$ & $\begin{array}{c}(6) \\
\text { Entropy }\end{array}$ \\
\hline Lagged $\log ($ enrollment $)$ & $\begin{array}{l}-0.005 \\
{[0.011]}\end{array}$ & $\begin{array}{c}-0.001 \\
{[0.007]}\end{array}$ & $\begin{array}{c}0.003 \\
{[0.006]}\end{array}$ & $\begin{array}{c}-0.004 \\
{[0.011]}\end{array}$ & $\begin{array}{l}-0.007 \\
{[0.007]}\end{array}$ & $\begin{array}{c}0.005 \\
{[0.006]}\end{array}$ \\
\hline Log(land area) & $\begin{array}{c}0.066^{* * * *} \\
{[0.008]}\end{array}$ & $\begin{array}{c}0.039 \\
{[0.005]}\end{array}$ & $\begin{array}{c}0.041 * * * \\
{[0.004]}\end{array}$ & $\begin{array}{c}0.066^{* * *} \\
{[0.008]}\end{array}$ & $\begin{array}{c}0.038 * * * \\
{[0.005]}\end{array}$ & $\begin{array}{c}0.040 * * * \\
{[0.004]}\end{array}$ \\
\hline Lagged \%NW District & $\begin{array}{c}0.972 * * * \\
{[0.029]}\end{array}$ & $\begin{array}{c}0.157 * * * \\
{[0.019]}\end{array}$ & $\begin{array}{c}0.230 * * * \\
{[0.015]}\end{array}$ & $\begin{array}{c}0.973 * * * \\
{[0.029]}\end{array}$ & $\begin{array}{c}0.159 * * * \\
{[0.019]}\end{array}$ & $\begin{array}{c}0.231 * * * \\
{[0.015]}\end{array}$ \\
\hline \multicolumn{7}{|c|}{ Type (omitted central city) } \\
\hline Consolidated & $\begin{array}{c}-0.158 * * * \\
{[0.019]}\end{array}$ & $\begin{array}{c}-0.039 * * * \\
{[0.012]}\end{array}$ & $\begin{array}{c}-0.076 * * * \\
{[0.010]}\end{array}$ & $\begin{array}{c}-0.154 * * * \\
{[0.019]}\end{array}$ & $\begin{array}{c}-0.031 * * \\
{[0.013]}\end{array}$ & $\begin{array}{c}-0.072 * * * \\
{[0.010]}\end{array}$ \\
\hline Suburban & $\begin{array}{c}-0.101 * * * \\
{[0.107]}\end{array}$ & $\begin{array}{l}-0.021 * \\
{[0.011]}\end{array}$ & $\begin{array}{c}-0.043 * * * \\
{[0.009]}\end{array}$ & $\begin{array}{c}-0.099 * * * \\
{[0.017]}\end{array}$ & $\begin{array}{l}-0.015 \\
{[0.011]}\end{array}$ & $\begin{array}{c}-0.040 * * * \\
{[0.009]}\end{array}$ \\
\hline \multicolumn{7}{|l|}{$\begin{array}{l}\text { Federal circuit (omitted } \\
\text { Fifth) }\end{array}$} \\
\hline Fourth Circuit & $\begin{array}{l}-0.031 \\
{[0.026]}\end{array}$ & $\begin{array}{c}0.024 \\
{[0.017]}\end{array}$ & $\begin{array}{l}-0.021 \\
{[0.013]}\end{array}$ & $\begin{array}{c}-0.035^{* *} \\
{[0.014]}\end{array}$ & $\begin{array}{c}0.005 \\
{[0.009]}\end{array}$ & $\begin{array}{c}-0.007 \\
{[0.007]}\end{array}$ \\
\hline Eleventh Circuit & $\begin{array}{c}0.034 * * \\
{[0.015]}\end{array}$ & $\begin{array}{c}0.024 * * \\
{[0.010]}\end{array}$ & $\begin{array}{c}0.020 * * * \\
{[0.008]}\end{array}$ & $\begin{array}{c}0.035 * * \\
{[0.015]}\end{array}$ & $\begin{array}{c}0.025 * * \\
{[0.010]}\end{array}$ & $\begin{array}{c}0.021 * * * \\
{[0.008]}\end{array}$ \\
\hline All Others & $\begin{array}{c}0.048 * * \\
{[0.019]}\end{array}$ & $\begin{array}{c}0.041 * * * \\
{[0.012]}\end{array}$ & $\begin{array}{c}0.043 * * * \\
{[0.009]}\end{array}$ & $\begin{array}{c}0.049 * * \\
{[0.019]}\end{array}$ & $\begin{array}{c}0.045 * * * \\
{[0.013]}\end{array}$ & $\begin{array}{c}0.044 * * * \\
{[0.010]}\end{array}$ \\
\hline Unitary status & $\begin{array}{c}0.015 \\
{[0.013]}\end{array}$ & $\begin{array}{c}0.039 * * * \\
{[0.009]}\end{array}$ & $\begin{array}{c}0.022 * * * \\
{[0.007]}\end{array}$ & - & - & - \\
\hline
\end{tabular}




\begin{tabular}{|c|c|c|c|c|c|c|}
\hline $\begin{array}{l}\text { Fourth Circuit*Linear time } \\
\text { trend (Year-1992) }\end{array}$ & $\begin{array}{l}-0.001 \\
{[0.004]}\end{array}$ & $\begin{array}{l}0.005^{* *} \\
{[0.002]}\end{array}$ & $\begin{array}{c}0.003 \\
{[0.002]}\end{array}$ & - & - & - \\
\hline Declared unitary this year & - & - & - & $\begin{array}{c}0.005 \\
{[0.035]}\end{array}$ & $\begin{array}{l}-0.005 \\
{[0.023]}\end{array}$ & $\begin{array}{c}0.001 \\
{[0.018]}\end{array}$ \\
\hline $\begin{array}{l}\text { Declared unitary one year } \\
\text { ago }\end{array}$ & - & - & - & $\begin{array}{c}0.001 \\
{[0.039]}\end{array}$ & $\begin{array}{l}-0.005 \\
{[0.025]}\end{array}$ & $\begin{array}{l}-0.003 \\
{[0.020]}\end{array}$ \\
\hline $\begin{array}{l}\text { Declared unitary two years } \\
\text { ago }\end{array}$ & - & - & - & $\begin{array}{l}-0.027 \\
{[0.040]}\end{array}$ & $\begin{array}{c}-0.003 \\
{[0.026]}\end{array}$ & $\begin{array}{l}-0.001 \\
{[0.021]}\end{array}$ \\
\hline $\begin{array}{l}\text { Declared unitary three or } \\
\text { more years ago }\end{array}$ & - & - & - & $\begin{array}{c}0.022 \\
{[0.015]}\end{array}$ & $\begin{array}{c}0.053^{* * *} \\
{[0.010]}\end{array}$ & $\begin{array}{c}0.029 * * * \\
{[0.008]}\end{array}$ \\
\hline Year fixed effects & Yes & Yes & Yes & Yes & Yes & Yes \\
\hline Observations & 1061 & 1061 & 1061 & 1061 & 1061 & 1061 \\
\hline $\mathbf{R}^{2}$ & .72 & .20 & .41 & .72 & .20 & .41 \\
\hline
\end{tabular}

Note: No GA observations for 2003 due to missing lag of NW\%

$11 / 4 / 04$ 
Table 5: Regressions Explaining Segregation and Racial Isolation, Pooled Sample with District Fixed Effects

\begin{tabular}{|c|c|c|c|c|c|c|}
\hline & (1) & (2) & (3) & (4) & (5) & (6) \\
\hline & $\begin{array}{c}\% \mathrm{~B} 90- \\
100 \% \mathrm{NW}\end{array}$ & $\begin{array}{c}\text { W-NW } \\
\text { seg. }\end{array}$ & Entropy & $\begin{array}{c}\% \mathrm{~B} 90- \\
100 \% \mathrm{NW}\end{array}$ & $\begin{array}{c}\text { W-NW } \\
\text { seg. }\end{array}$ & Entropy \\
\hline $\begin{array}{l}\text { Lagged } \\
\log (\text { enrollment })\end{array}$ & $\begin{array}{c}-0.172 * * * \\
{[0.027]}\end{array}$ & $\begin{array}{c}0.044 * * * \\
{[0.013]}\end{array}$ & $\begin{array}{c}0.011 \\
{[0.012]}\end{array}$ & $\begin{array}{c}-0.169 * * * \\
{[0.027]}\end{array}$ & $\begin{array}{c}0.045 * * * \\
{[0.013]}\end{array}$ & $\begin{array}{c}0.013 \\
{[0.012]}\end{array}$ \\
\hline Lagged \%NW & $\begin{array}{c}0.762 * * * \\
{[0.078]}\end{array}$ & $\begin{array}{c}0.004 \\
{[0.038]}\end{array}$ & $\begin{array}{l}0.087 * * \\
{[0.035]}\end{array}$ & $\begin{array}{c}0.782 * * * \\
{[0.077]}\end{array}$ & $\begin{array}{c}0.015 \\
{[0.038]}\end{array}$ & $\begin{array}{c}0.096 * * * \\
{[0.035]}\end{array}$ \\
\hline Unitary status & $\begin{array}{c}0.014 \\
{[0.009]}\end{array}$ & $\begin{array}{c}0.004 \\
{[0.005]}\end{array}$ & $\begin{array}{c}0.011^{* * * *} \\
{[0.004]}\end{array}$ & - & - & - \\
\hline $\begin{array}{l}\text { Unitary status } \\
\text { current year }\end{array}$ & - & - & - & $\begin{array}{l}-0.001 \\
{[0.012]}\end{array}$ & $\begin{array}{l}-0.006 \\
{[0.006]}\end{array}$ & $\begin{array}{c}0.003 \\
{[0.006]}\end{array}$ \\
\hline $\begin{array}{l}\text { Unitary status past } \\
\text { year }\end{array}$ & - & - & - & $\begin{array}{c}0.015 \\
{[0.014]}\end{array}$ & $\begin{array}{c}0.002 \\
{[0.007]}\end{array}$ & $\begin{array}{c}0.009 \\
{[0.006]}\end{array}$ \\
\hline $\begin{array}{l}\text { Unitary status two } \\
\text { years ago }\end{array}$ & - & - & - & $\begin{array}{c}0.004 \\
{[0.014]}\end{array}$ & $\begin{array}{c}0.009 \\
{[0.007]}\end{array}$ & $\begin{array}{l}0.012^{*} \\
{[0.006]}\end{array}$ \\
\hline $\begin{array}{l}\text { Unitary status } \\
\text { three or more } \\
\text { years ago }\end{array}$ & - & - & - & $\begin{array}{c}0.055^{* * * *} \\
{[0.013]}\end{array}$ & $\begin{array}{c}0.022 * * * \\
{[0.007]}\end{array}$ & $\begin{array}{c}0.030 * * * \\
{[0.006]}\end{array}$ \\
\hline $\mathrm{N}$ & 1061 & 1061 & 1061 & 1061 & 1061 & 1061 \\
\hline $\mathrm{R}^{2}$ & .48 & .04 & .31 & .50 & .07 & .31 \\
\hline $\begin{array}{l}\text { Year fixed } \\
\text { effects? }\end{array}$ & Yes & Yes & Yes & Yes & Yes & Yes \\
\hline
\end{tabular}

$11 / 24 / 04$ 
Figure 1. Measures of Segregation, Isolation, and Interracial Exposure, 100 Districts, 1993/94 to 2003/04.

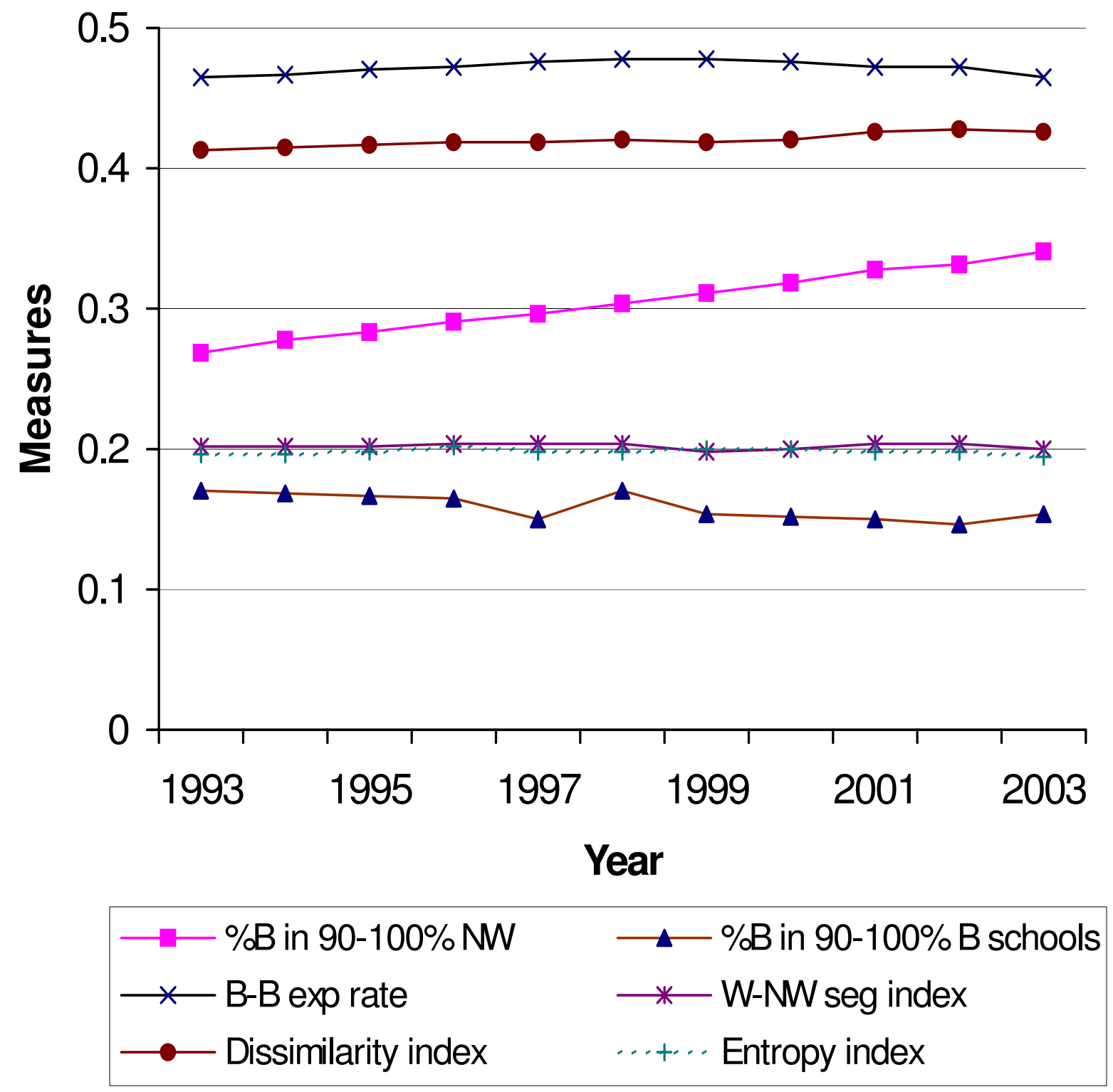

Note: Data interpolated for 5 districts in TN due to missing data in 1997, 1999-2002.

$11 / 30 / 04$ 
Figure 2. Exposure Rates by Race and Overall Racial Composition, 100 Districts, 1993/94 and 2003/04

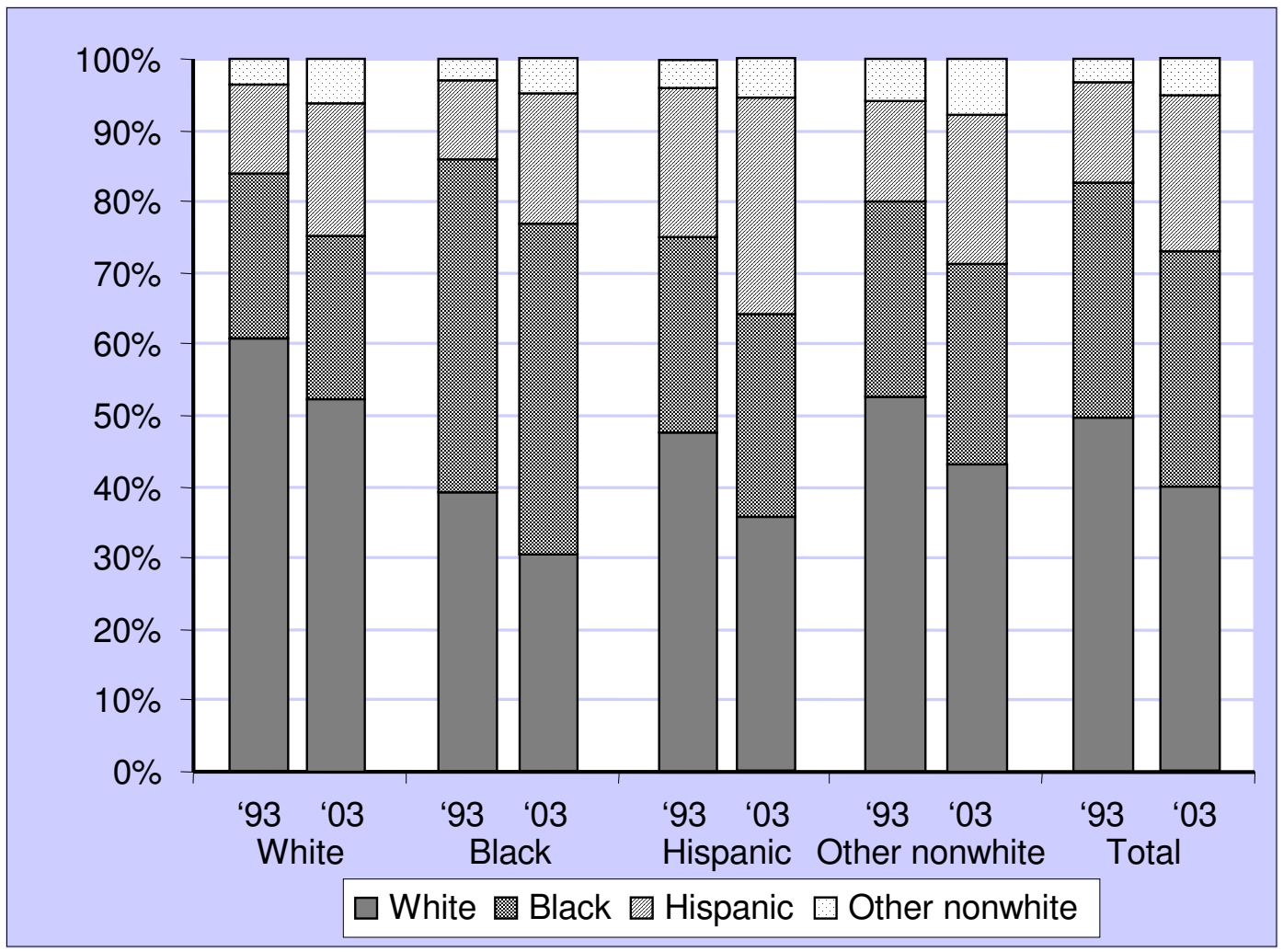

Source: See Table 1.

Note: Each of the first eight bars gives the racial composition for the school attended by the typical student of each indicated racial group for the indicated year. The last two bars give the overall racial composition of schools in the 100 districts. 
Figure 3. Racial Composition and White Growth Rate, 1993/94 - 2003/04

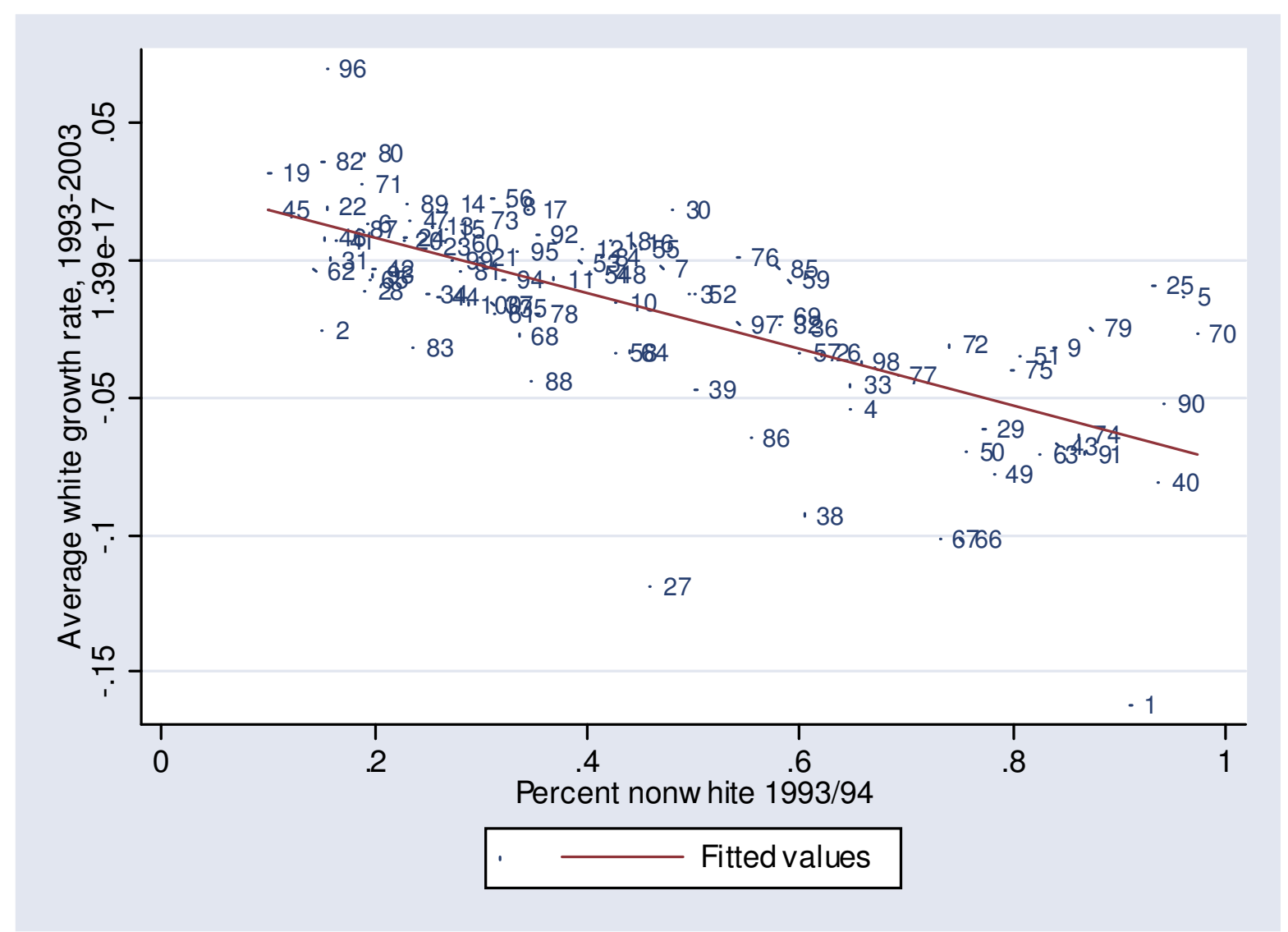

Source: See Table 1 
Figure 4. White-nonwhite Segregation Index, 1993/94 and 2003/04

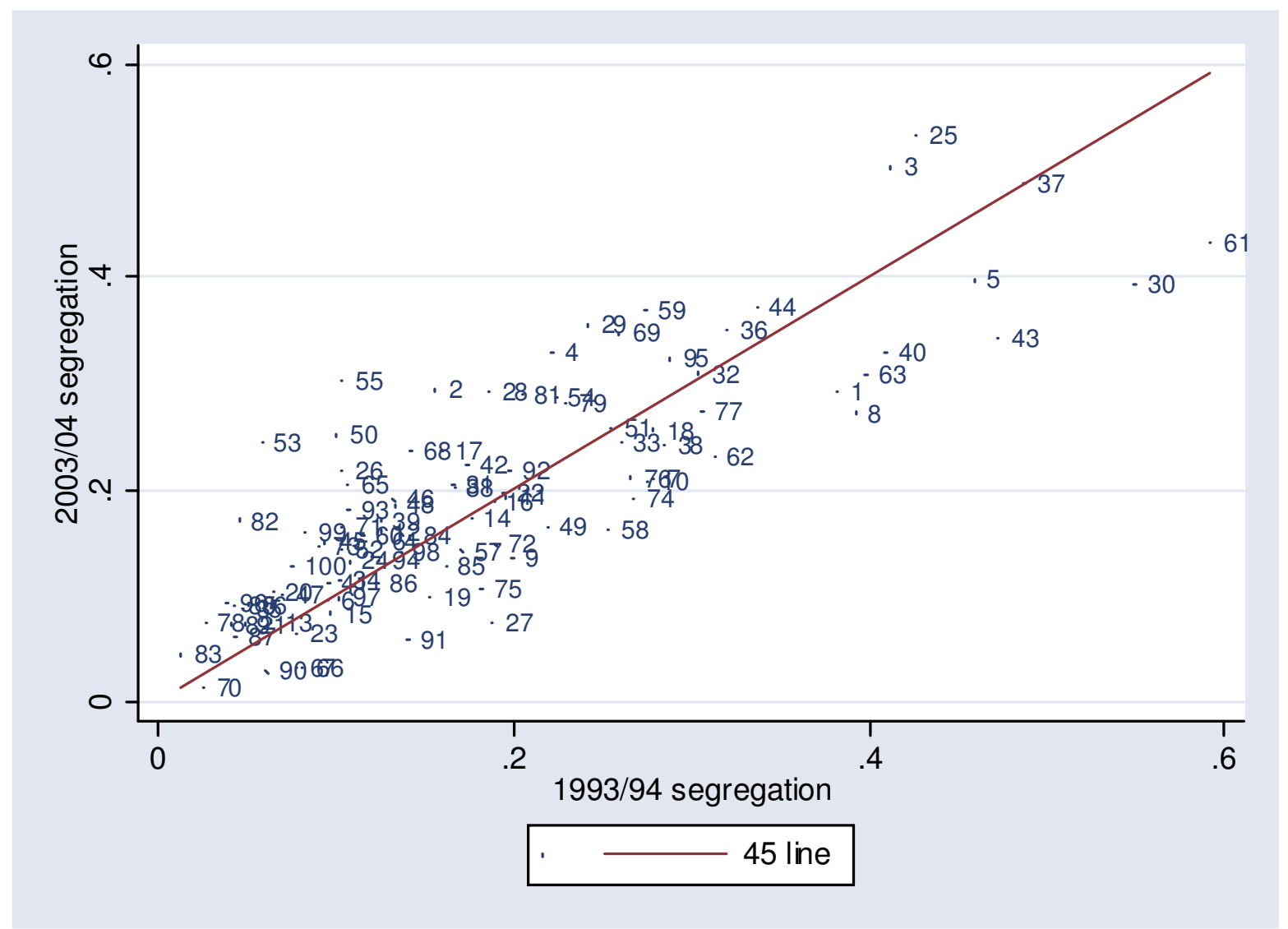

Source: See Table 1 
Figure 5. Percentage of Black Students in 90-100\% Nonwhite Schools, 1993/94 and 2003/04

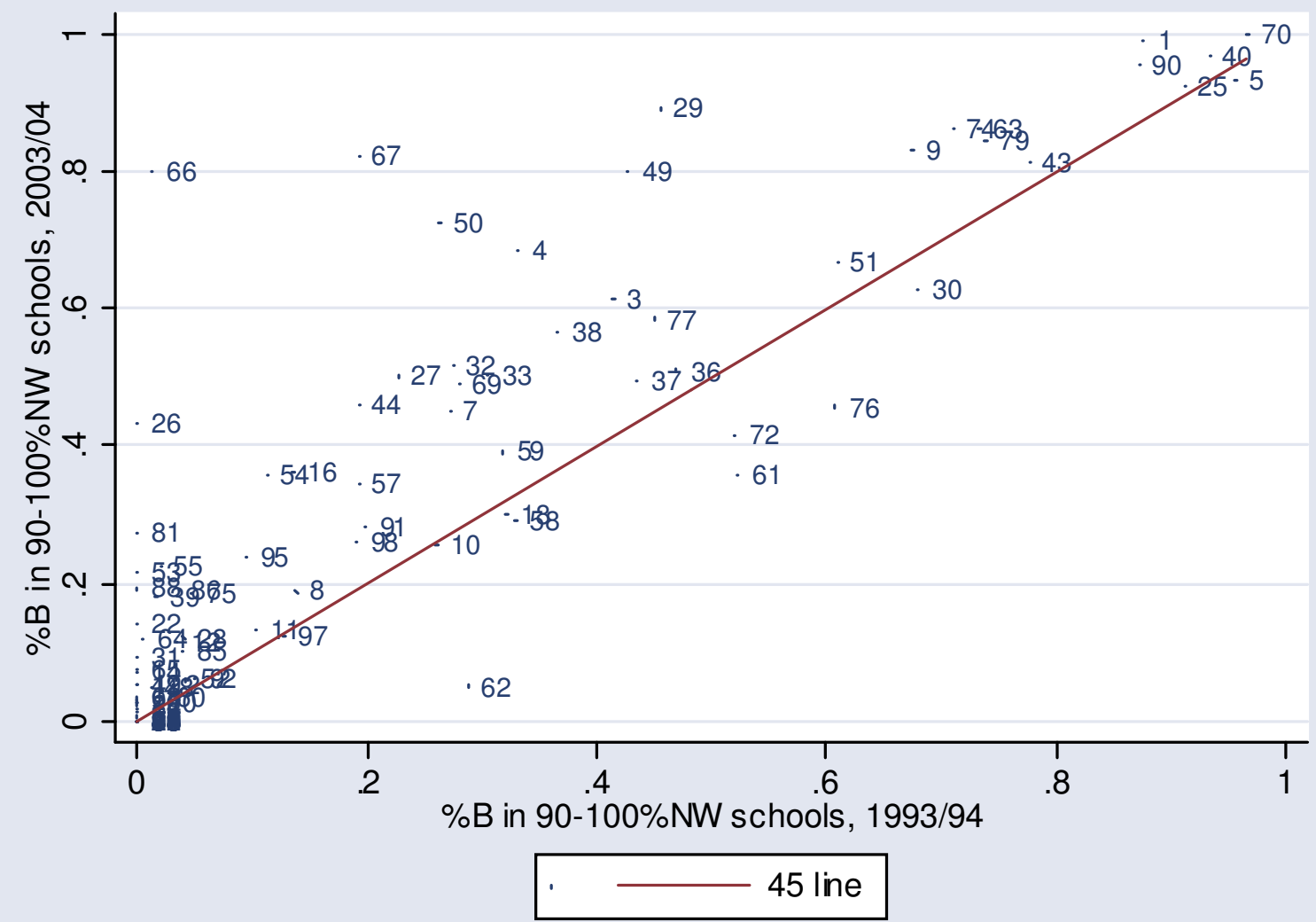

Source: See Table 1 
Figure 6. Districts in Sample with Unitary Status (fraction of total enrollment)

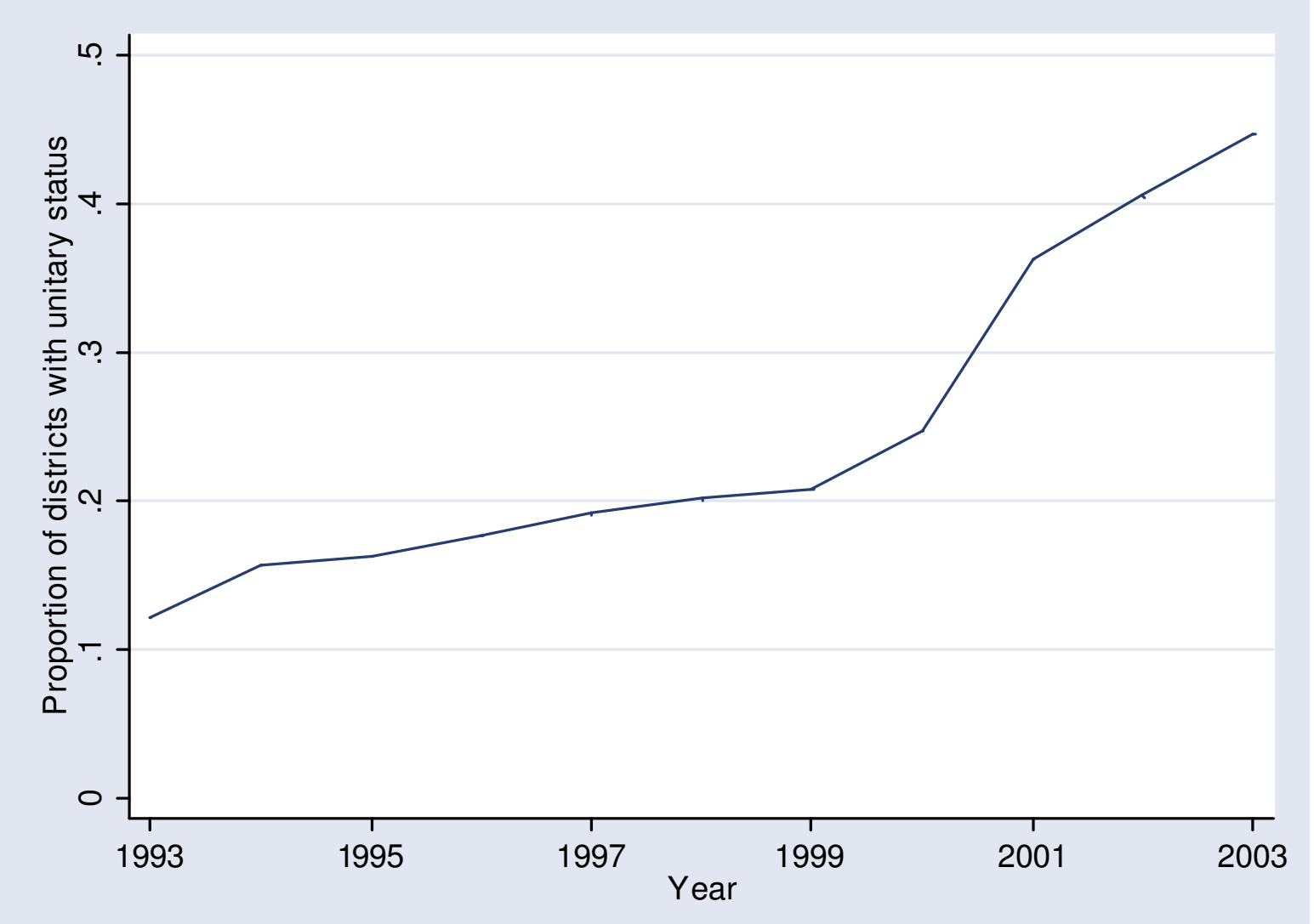

Source: See text 
Appendix Table 1. 100 Largest School Districts in South and Border States, 2003/04.

\begin{tabular}{|c|c|c|c|c|c|c|c|c|c|}
\hline State & District & Obs.\# & Enrollment & $\begin{array}{c}\text { Percent } \\
\text { nonwhite } \\
(\%)\end{array}$ & $\begin{array}{c}\text { Segregation } \\
\text { index }\end{array}$ & $\begin{array}{c}\text { Dissimilarity } \\
\text { index }\end{array}$ & $\begin{array}{c}\text { Percentage } \\
\text { black students } \\
\text { in schools } \\
90-100 \% \\
\text { nonwhite }(\%)\end{array}$ & $\begin{array}{l}\text { Entropy } \\
\text { measure }\end{array}$ & $\begin{array}{c}\text { Unitary } \\
\text { status }\end{array}$ \\
\hline \multirow[t]{4}{*}{ Alabama } & Birmingham City & 01 & 34,377 & 98.1 & 0.291 & 0.653 & 99.1 & .341 & \\
\hline & Jefferson Co. & 02 & 38,631 & 30.7 & 0.293 & 0.468 & 5.4 & .244 & \\
\hline & Mobile Co. & 03 & 64,975 & 54.1 & 0.503 & 0.646 & 61.6 & .432 & 1997 \\
\hline & Montgomery Co. & 04 & 32,521 & 78.1 & 0.329 & 0.614 & 68.7 & .310 & \\
\hline $\mathrm{DC}$ & D.C. Public Schools & 05 & 58,075 & 95.4 & 0.397 & 0.854 & 93.5 & .448 & \\
\hline \multirow[t]{19}{*}{ Florida } & Brevard Co. & 06 & 75,800 & 24.5 & 0.096 & 0.285 & 0.0 & .095 & \\
\hline & Broward Co. & 07 & 271,353 & 64.5 & 0.210 & 0.393 & 45.3 & .194 & 1994 \\
\hline & Collier Co. & 08 & 38,347 & 50.5 & 0.272 & 0.438 & 18.8 & .180 & \\
\hline & Dade Co. & 09 & 358,173 & 89.9 & 0.136 & 0.456 & 83.3 & .330 & 2001 \\
\hline & Duval Co. & 10 & 123,786 & 53.2 & 0.207 & 0.358 & 25.5 & .174 & 2001 \\
\hline & Escambia Co. & 11 & 44,572 & 42.4 & 0.193 & 0.353 & 13.4 & .146 & \\
\hline & Hillsborough Co. & 12 & 181,504 & 53.9 & 0.161 & 0.339 & 11.7 & .136 & 2001 \\
\hline & Lee Co. & 13 & 64,758 & 39.4 & 0.076 & 0.246 & 0.0 & .082 & 2004 \\
\hline & Manatee Co. & 14 & 41,843 & 37.5 & 0.172 & 0.338 & 7.0 & .116 & \\
\hline & Marion Co. & 15 & 39,983 & 34.6 & 0.084 & 0.236 & 1.2 & .084 & 1995 \\
\hline & Orange Co. & 16 & 168,334 & 60.4 & 0.190 & 0.369 & 36.4 & .185 & \\
\hline & Osceola Co. & 17 & 43,874 & 59.2 & 0.236 & 0.416 & 2.0 & .132 & \\
\hline & Palm Beach Co. & 18 & 171,848 & 56.5 & 0.256 & 0.448 & 30.3 & .202 & 2002 \\
\hline & Pasco Co. & 19 & 55,859 & 17.4 & 0.099 & 0.277 & 5.2 & .091 & \\
\hline & Pinellas Co. & 20 & 119,948 & 31.6 & 0.105 & 0.296 & 0.0 & .095 & 2000 \\
\hline & Polk Co. & 21 & 80,982 & 40.2 & 0.073 & 0.215 & 0.0 & .077 & 2000 \\
\hline & Sarasota Co. & 22 & 39,273 & 23.4 & 0.197 & 0.367 & 14.1 & .162 & \\
\hline & Seminole Co. & 23 & 64,192 & 36.3 & 0.063 & 0.209 & 0.0 & .055 & \\
\hline & Volusia Co. & 24 & 63,383 & 29.9 & 0.132 & 0.309 & 0.0 & .148 & \\
\hline \multirow[t]{2}{*}{ Georgia } & Atlanta City & 25 & 51,315 & 92.8 & 0.534 & 0.847 & 92.4 & .479 & 1975 \\
\hline & Chatham Co. & 26 & 33,364 & 71.7 & 0.218 & 0.440 & 43.5 & .189 & 1994 \\
\hline
\end{tabular}




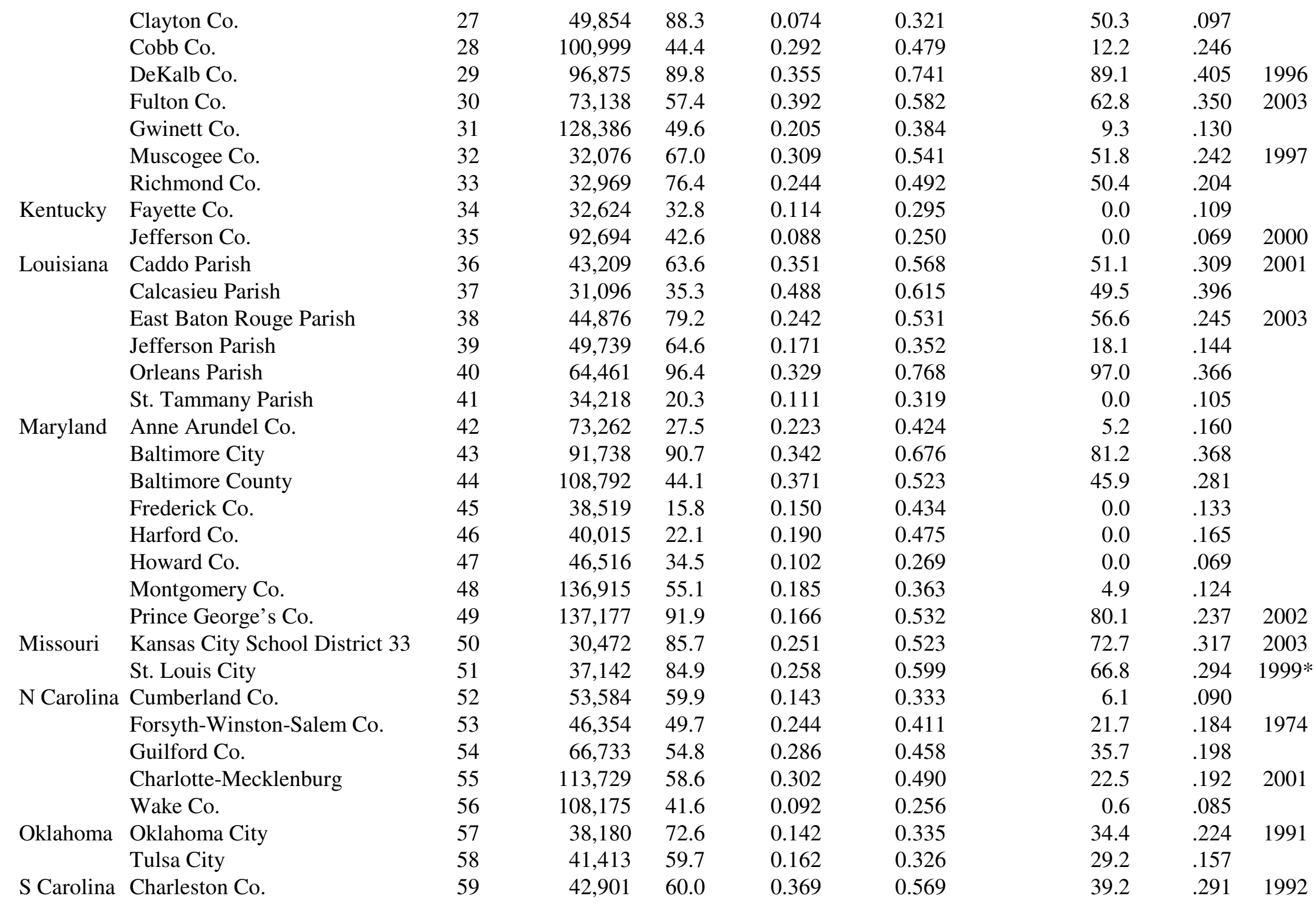




\begin{tabular}{|c|c|c|c|c|c|c|c|c|c|}
\hline \multirow{6}{*}{ Tennessee } & Greenville Co. & 60 & 63,452 & 35.6 & 0.156 & 0.321 & 3.5 & .118 & 1985 \\
\hline & Hamilton Co. & 61 & 40,507 & 38.3 & 0.433 & 0.564 & 36.0 & .352 & 1986 \\
\hline & Knox Co. & 62 & 52,698 & 18.1 & 0.232 & 0.415 & 5.1 & .214 & \\
\hline & Memphis City & 63 & 116,857 & 92.1 & 0.308 & 0.710 & 86.2 & .340 & \\
\hline & Nashville-Davidson Co. & 64 & 70,002 & 59.7 & 0.151 & 0.316 & 11.9 & .152 & 1998 \\
\hline & Shelby Co. & 65 & 47,042 & 33.1 & 0.204 & 0.366 & 7.5 & .154 & \\
\hline \multirow{26}{*}{ Texas } & Aldine & 66 & 53,086 & 93.3 & 0.031 & 0.251 & 79.9 & .089 & \\
\hline & Alief & 67 & 43,188 & 93.1 & 0.032 & 0.279 & 82.5 & .045 & \\
\hline & Arlington & 68 & 59,301 & 59.3 & 0.237 & 0.425 & 3.4 & .142 & \\
\hline & Austin & 69 & 73,922 & 68.3 & 0.347 & 0.564 & 49.0 & .150 & 1983 \\
\hline & Brownsville & 70 & 42,687 & 98.1 & 0.014 & 0.379 & 100.0 & .095 & \\
\hline & Conroe & 71 & 38,102 & 28.4 & 0.164 & 0.348 & 0.0 & .126 & \\
\hline & Corpus Christi & 72 & 37,899 & 79.4 & 0.148 & 0.419 & 41.6 & .128 & \\
\hline & Cypress-Fairbanks & 73 & 72,623 & 47.2 & 0.147 & 0.318 & 0.0 & .084 & \\
\hline & Dallas & 74 & 152,684 & 93.6 & 0.192 & 0.600 & 86.1 & .301 & 2003 \\
\hline & El Paso & 75 & 60,615 & 86.5 & 0.106 & 0.408 & 18.7 & .155 & \\
\hline & Fort Bend & 76 & 60,067 & 68.0 & 0.211 & 0.439 & 45.8 & .218 & \\
\hline & Fort Worth & 77 & 76,080 & 81.6 & 0.273 & 0.552 & 58.6 & .302 & 1990 \\
\hline & Garland & 78 & 53,259 & 59.7 & 0.074 & 0.233 & 0.0 & .062 & \\
\hline & Houston & 79 & 195,686 & 90.4 & 0.282 & 0.664 & 84.6 & .344 & 1983 \\
\hline & Katy & 80 & 40,881 & 35.6 & 0.090 & 0.273 & 0.0 & .083 & \\
\hline & Klein & 81 & 34,645 & 44.7 & 0.290 & 0.482 & 27.6 & .162 & \\
\hline & Lewisville & 82 & 43,249 & 30.9 & 0.172 & 0.373 & 0.0 & .141 & \\
\hline & Mesquite & 83 & 33,591 & 53.9 & 0.044 & 0.187 & 0.0 & .042 & \\
\hline & North East & 84 & 55,035 & 54.2 & 0.156 & 0.339 & 2.5 & .114 & \\
\hline & Northside & 85 & 69,453 & 68.2 & 0.127 & 0.326 & 10.4 & .090 & \\
\hline & Pasadena & 86 & 43,922 & 80.0 & 0.111 & 0.344 & 19.1 & .142 & \\
\hline & Plano & 87 & 50,228 & 37.1 & 0.060 & 0.192 & 0.0 & .085 & \\
\hline & Richardson & 88 & 33,205 & 58.7 & 0.202 & 0.374 & 19.3 & .166 & \\
\hline & Round Rock & 89 & 34,792 & 39.0 & 0.073 & 0.225 & 0.0 & .083 & \\
\hline & San Antonio & 90 & 52,697 & 96.3 & 0.028 & 0.322 & 95.6 & .253 & \\
\hline & Ysleta & 91 & 44,769 & 93.1 & 0.059 & 0.447 & 28.4 & .124 & \\
\hline Virginia & Chesapeake City & 92 & 39,412 & 40.2 & 0.218 & 0.410 & 6.2 & .160 & \\
\hline
\end{tabular}




\begin{tabular}{|c|c|c|c|c|c|c|c|c|}
\hline Chesterfield Co. & 93 & 54,124 & 32.8 & 0.181 & 0.354 & 0.0 & .129 & 1972 \\
\hline Fairfax Co. & 94 & 161,890 & 47.1 & 0.133 & 0.305 & 2.9 & .105 & \\
\hline Henrico Co. & 95 & 43,958 & 45.3 & 0.323 & 0.496 & 23.8 & .276 & 1972 \\
\hline Loudoun Co. & 96 & 39,004 & 27.9 & 0.094 & 0.265 & 0.0 & .074 & \\
\hline Newport News City & 97 & 31,142 & 64.2 & 0.097 & 0.250 & 12.4 & .076 & \\
\hline Norfolk City & 98 & 32,650 & 74.3 & 0.141 & 0.351 & 26.1 & .123 & $1986^{*}$ \\
\hline Prince William Co. & 99 & 64,192 & 49.0 & 0.159 & 0.344 & 0.0 & .095 & \\
\hline Virginia Beach City & 100 & 75,900 & 40.0 & 0.127 & 0.305 & 2.8 & .085 & \\
\hline
\end{tabular}

* No official designation of unitary status, but effectively treated by courts as such.

Source: Tabulations provided by school districts; authors' calculations.

Note: Following Orfield and Monfort (1992, p. 2), regions are defined as follows: Border: Delaware, District of Columbia, Kentucky, Maryland, Missouri, Oklahoma, West Virginia; South: Alabama, Arkansas, Florida, Georgia, Louisiana, Mississippi, North Carolina, South Carolina, Tennessee, Texas, Virginia.

\section{$11 / 16 / 04$}

